\title{
Marketing (as) Rhetoric: paradigms, provocations, and perspectives.
}

\author{
Stephen Brown, Chris Hackley, Shelby D. Hunt, Charles Marsh, Nicholas O'Shaughnessy, \\ Barbara J. Phillips, David Tonks, Chris Miles, and Tomas Nilsson
}

Introduction

\section{By Chris Miles \& Tomas Nilsson}

It is an honour and immense pleasure for us to introduce the seven invited contributions to the special section on marketing (as) rhetoric. Altogether these contributions illustrate how different rhetorical approaches can be used self-reflexively to ask new questions and gain new insights into a wide range of marketing issues. Although there might be conflicting understandings of rhetoric here, there is a clear agreement across all voices that rhetoric brings something valuable to the marketing discipline, which bodes well for the continuing evolution of research on marketing (as) rhetoric.

Stephen Brown, resembling a modern Gorgias, starts us out with a typically playful display of rhetorical fireworks, this time in the service of reviewing the longstanding rhetorical success of "our profession's preeminent mnemonic", the 4Ps. Even though we might all agree on the poverty of explanatory potential of the 4P model, and are heartily tired of repeating it, the 4P nonetheless doggedly haunt our marketing courses, our textbooks, our conferences, and (increasingly important) our discipline's presence in the free knowledge store of the Internet. Why is this so? Brown argues that the magic of the marketing mix is to be found in its perfectly tuned rhetorical construction.

Chris Hackley argues that "greater understanding of rhetorically oriented research in marketing can help to render marketing studies more relevant to current marketing, advertising and branding practices in the age of social media". This is particularly important in the field of "critical marketing" where a rhetorical approach to marketing enables us to critically uncover "the techniques, practices and modes of circulation that characterise the spread of ideological communication". While there is a slowly growing stream of rhetorically-informed marketing scholarship, Hackley notes that this suffers both from a lack of thematic unity, and a lack of substantial use of the classical rhetorical tradition. To stimulate further development of explicitly rhetorical approaches in the marketing discipline, we need to work harder to conceptually connect rhetorical theory and modern marketing frameworks and paradigms.

Shelby Hunt's contribution takes Tonks' (2002) Aristotelian definition of rhetoric as a starting point to argue that the "inductive realist model of theory generation" (Hunt, 2012, 2013) "incorporates rhetorical processes" as well as those of discovery and justification. Hunt does this through an intriguing recounting of the rhetorical choices that he and Robert Morgan had to make in order to get their foundational exposition of Resource-Advantage Theory accepted in the Journal of Marketing (Hunt and Morgan, 1995). In contrast to Brown's consideration of the Gorgian stylistic characteristics that have served the 4Ps so well, Hunt's focus is an appreciation of the rhetorical argumentation that marketing 
scholars need to employ to ensure the highest chances of their journal submissions not being rejected outright. Authors must anticipate reviewer objections and rhetorically construct the presentation of their theories to forestall those objections.

Charles Marsh has long been a learned champion of using the rhetorical system of Isocrates as a framework for a modern, civic-minded approach to the teaching and practice of public relations (Marsh, 2013). In his contribution he extends this to a broader consideration of what Isocrates' rhetoric has to offer contemporary marketing. In contrast to Brown's focus on the power of the elements of rhetorical style, Marsh's argument focuses on the persuasiveness of a speaker's established reputation. Marsh demonstrates how Isocrates' lessons regarding the cultivation and maintenance of such a reputation have important ramifications for how we should conduct modern marketing.

Already in our first four contributions, then, we have representatives of the Sophistic (Gorgian), Aristotelian, and Isocratean rhetorical traditions. At this point Nicholas O'Shaughnessy arrives to discuss what happens when political marketing, as both an academic discipline and practice, ignores the rhetorical perspective. O'Shaughnessy argues that Trump "repudiates entirely any political marketing script that existed". The evidenced, sensible, rational strategies of political marketing are worlds away from Trump's "outlandish persona" and its constant rhetorical reinforcement. O'Shaughnessy identifies Trump as a de-marketer, anti-marketer, or unmarketer. In this sense, Trump's approach is also antiAristotelian and, we might venture, pro-Gorgian. The rhetoric of Gorgias, the ur-Sophist, is often characterised as shifting, enchanting, morally ambiguous, and appealing to the emotional, irrational side of the audience. Aristotle's rhetoric focuses on the construction of convincing arguments that can be helped by being wrapped in a clear, simple style that aids their appreciation. Gorgian rhetoric delights in the surreal interface between logos, emotion, and magic. Political marketing has for too long operated on Aristotelian grounds. O'Shaughnessy contribution argues that Trump's resurrection of the Gorgian approach directly challenges the discipline's identity and future relevance.

While Trump might represent one side of the Sophistic tradition of rhetoric, Barbara Phillips's contribution reminds us of another. The pleasure and play of rhetoric are essential to keep in mind when we try to explore why we use rhetoric and why we react to it in the way we do. Advertising rhetoric evokes "the pleasures of the text in consumers' minds". We enjoy a pun and gain pleasure from a well-formed piece of alliteration. Metaphors are not just informative, we appreciate them and the process of unlocking the terms of their comparison. Therefore, as Phillips argues, pleasure and play lie "at the core of advertising rhetoric". Appreciating the importance of play in the processing of advertising allows us, in turn, to focus on the role of imagination. Phillips draws upon Vygotsky's laws of imagination to enrich not only advertising scholarship but also more general rhetorical scholarship around the relationships between audiences and figurative language.

Although we have arranged the authors alphabetically it is entirely fitting that we end with David Tonks. Tonks' (2002) paper for JMM -Marketing as Cooking: Return of the Sophists - has been an important source of inspiration for us in our own work on marketing and rhetoric, and one of the main reasons for putting together this special section, in the journal that originally hosted Tonks' paper. Here, Tonks 
reflects on the ideas behind the 2002 paper, and reiterates the continuing need for marketing scholars to recognise the relationship between marketing and the art of persuasion. This relationship has been consistently elided from the grand theories that have sought to define the scope of marketing, even thuogh "the classic principles and devices of rhetoric remain fundamental" to marketing practitioners. Tonks suggests that this follows from a weak understanding of rhetoric at large in higher education, especially in the UK. He ends his reasoning with a hope that "the day will soon come when students on undergraduate or taught postgraduate programmes in marketing encounter an introductory text or a foundation module accurately titled Marketing: Rhetoric and Reality", with which we believe all the invited authors would agree. 


\title{
Are the Four Ps Finished? The Poetic Rhetoric of an Iconic Mnemonic
}

\author{
Stephen Brown
}

Product. Price. Place. Promotion. Few words are more used and abused by people like us than Product, Price, Place and Promotion (van Waterschoot, 1999). First collated by McCarthy (1960) in his celebrated introductory textbook -- albeit based on several earlier inventories of the marketing mix (Sheth et al, 1988) -- the 4Ps is what literary critics call a holophrasm. That is to say, it is a thumbnail sketch, an encapsulation, a precis, nothing less than marketing in miniature, the subject in a nutshell. Even those who know nothing about marketing know about the 4Ps. It is our profession's preeminent mnemonic, ahead of USP, STP, SWOT, PEST and all the rest (Kotler, 2003, 2008).

That said, the very felicity of the 4Ps has led to accusations of facility (Constantinides, 2006). For more than a few gurus it is a vapid abbreviation, a crude condensation, a glib oversimplification, a fatuous, formulaic, fallacious framework that's not only out of date but grotesquely misrepresents the nature of marketing science (Grönroos, 1994; Rafiq and Ahmed, 1995; Vignali and Davies, 1994). The 4Ps is a noose around marketing's neck, the albatross of thought. And while it may have a place in For Dummies handbooks or Idiot's Guides to our field, it is a sheet anchor on ship-shape marketing scholarship. ${ }^{1}$ The 4Ps, Kent (1986, p. 150) contends, "have seriously misled students, researchers, academics and practitioners alike into a fake sense of simplicity." 


\section{To P or Not to P?}

Speaking personally, I have always had a soft spot for the Ps. As someone who drifted into marketing from an adjacent academic discipline, the primal Ps gave me a feel for the subject and a much-needed sense of direction. A stranger in a strange land, the 4Ps were the cardinal points of my conceptual compass. They were also responsible for one of my most humiliating pedagogic experiences. As a rookie lecturer, I once "reminded" a large undergraduate class of the four paradigmatic Ps and couldn't remember one of them. Place, I think it was. What made it worse was the embarrassing fact that, earlier the same day, I'd been introduced to a colleague's pre-school children, one of whose party pieces was a word-perfect recitation of the 4Ps. Out of the mouths of babes...and precocious little brats!

My first reaction on being shown up by a four-year-old -- apart from shame, shame, shame - was to future-proof Stevie B's P-speak. I composed a piece of doggerel that kept me right when the urge to recite began to bite:

Product Place Price Promotion

Set the marketplace in motion

Even far across the ocean

Product Place Price Promotion

Product Place Price Promotion

Seek to stir up a commotion

And consumers' deep devotion 
Product Place Price Promotion ${ }^{2}$

As doggerel goes, it's undeniably barking. And, truth to tell, I haven't needed it for, oh, a couple of weeks or so. However, it always springs to mind when A.N. Other leading scholar takes potshots at the Ps or proffers their personal pre-prepared, pre-preferred, presumed-progressive, postPs proposition. Even back in the day, I couldn't help noticing that when yours truly mentioned the 4Ps, my older and wiser and, let's be honest, way more intelligent colleagues rolled their eyes or shook their heads at the newbie employee's naivety. They weren't alone in that regard. If there's one thing we can say for certain about the Four Ps, it is that the framework has been a whipping boy, a straw man, a fall guy - a crash-test dummy, if you will - for serious scholars, proper scholars, science-preoccupied and Nobel Prize-pursuing scholars. You know who you are...

\section{Scholars' Scrabble Squabble}

There's more to the 4Ps, though, than a roll of the eyes or shrug of the shoulders, when it lurches into view like the Frankenframework of thought (van Waterschoot and de Haes, 2008). Many attempts have been made to (1) repair it (2) replace it and (3) reinvent it. The repairers try to make 4Ps fit for purpose by taking latter-day marketing developments into account. This is usually achieved by adding to the inventory of Ps. Booms and Bitner (1981) famously added process, participants and physical evidence to our 4Ps pottage. Goldsmith (1999) threw in personalisation, personnel and procedures for good measure. And Kavanagh (2014) found two “forgotten" Ps, practice and phronesis, that had somehow fallen down the back of our saggy scholarly sofa. 
The replacers, by contrast, maintain that there's nothing to be gained by adding to the p-lethora. Peak $\mathrm{P}$ has been and gone. Ps are passé and, rather than contribute to the continuing consonantal confusion, a new initial is necessary. Lauterborn (1990) claims that the 4Cs of cost, convenience, communication and customer needs are just the ticket. ${ }^{3}$ Constantinides (2006) makes a case for the $4 \mathrm{~S}$ 's of scope, site, synergy and system. Jagdish Sheth is more of vowel man himself and duly dips into the big five for the 4As of acceptability, affordability, accessibility and awareness (Sheth and Sisodia, 2012). Bennett (1997), meanwhile, feels that victory $\mathrm{V}$ has what it takes for a takeover, five of them in fact.

Reinventors, on the other hand, accept that the 4Ps is too deeply seated to be superseded. For the most part, they feel that four and only four Ps will suffice. Reinventors, however, concede that the P-words themselves can be replaced with something more pertinent, propitious, provocative or, ideally, philosophical. One suggests that performance, penalty, perceptions and process will do the job (Yudelson, 1999). Another makes a case for production, perseverance, practice and personal branding (Lourenço, 2016). Yet another goes wild and crazy with permission, proximity, perception and participation (Forrester Research, 2009). And Ritson (2009), driven to distraction by the constant chopping and changing, caustically comments that "pointless" is surprisingly absent from this pantomime.

\section{Are 30Rs Ridiculous?}

As the above necessarily brief observations indicate, there's no shortage of attacks on, extensions of, and alternatives to the 4Ps framework (van Waterschoot, 1999). But have the decades of 
demonization demolished, denuded or destroyed the original? Are the four Ps, for want of a better word, fucked? The answer, amigos, is no, no way, not a chance. ${ }^{4}$ When this issue recently arose in a leading marketing trade magazine, which was triggered by CIM's (2016) official consecration of the 7Ps, there were just as many pro-4 as anti-P contributions to the ensuing debate among opinionated marketing practitioners (Bacon, 2017). The very fact that the mnemonic is still dividing opinion is testament to its iconicity.

It seems to me, though, that the debaters and commentators have missed a rhetorical trick or three. The first of these is that every attack on the original only serves to advertise it. Calling out involves calling up. In order to extirpate the extant inventory, it must be invoked. McCarthy's citation count continues to mount with every attempt to kill off his creation. Or as the early marketing guru Elbert Hubbard famously remarked, "every knock is a boost" (Brown, 2003). Until such times as alphabetti spaghetti is abandoned and an entirely different way of encapsulating the mix is concocted - an apt anagram, a deep-pan pie-chart, a four-ring Venn diagram or whatever ${ }^{5}$ - the Ps will remain in place, like the monumental American presidents on Mount Rushmore.

This talk of American monuments raises another monumental matter: Kotler. Although McCarthy is the scholar most associated with the 4Ps - albeit tribute is usually paid to Borden, Clewett, Culliton, etc. (Goi, 2009) -- Prince Philip did much to codify and promote the construct. Edition after edition after edition of His Royal Highness's hugely influential textbooks endorsed the 4Ps and, in effect, gave them the great man's seal of approval. Granted, the godfather of marketing once chucked a couple of jumbo shrimps on the P-barbie - politics and PR, to be 
precise -- but his ratification of the original is an important factor in the Ps' perpetuation (Kotler 2003). As he made clear during the naughties, when many posited that Ps were outdated in the digital marketing dispensation, "The 4Ps still provide a useful framework for marketing planning" (Kotler 2008, p. 61). ${ }^{6}$ In rhetoric, the speaker is as important as what's spoken (Adams, 2017). And, now that Levitt is no longer with us, no one speaks with greater authority than our top banana, King Kong Kolter.

Rhetoric, furthermore, doesn't stop at the door of Northwestern's imperishable nonesuch. There's also the question of parataxis. Parataxis is the rhetorical term for listing. And lists have an eloquence all of their own. As Dillon (2017) explains, part of the appeal of an inventory is its open-endedness. By their very nature lists are incomplete and, accordingly, there is an incessant, indeed irresistible temptation to add to them. Marketers are nothing if not parataxis addicted. Gummesson's 30R alternative to the 4Ps is arguably the most overindulgent instance of this propensity (Gummesson, 1997), but the inclination isn't confined to the marketing mix. Consider Service-Dominant Logic, which started with eight foundational premises, soon ballooned to eleven of the things and, in a moment of Honey-I Shrunk-the-SDL madness, it has since been boiled down to five (Vargo and Lusch, 2016). Why don't they just call their premises the four Ps plus one and be done with it? It only took them fifteen years to get there.

\section{And Another Thing}

A masterpiece of marketplace rhetoric (Miles, 2014), SDL remains hokum of the highest order (O'Shaughnessy and O'Shaughnessy, 2009). However, that's a charge that can never be levelled at the 4Ps. And why? Because the 4Ps are powered by another P-word that, perhaps more than 
anything else, perpetuates the precept. The P-word I'm referring to is poetry. In fifty-plus years of post-McCarthy debate, most of the discussion has focussed on pragmatic, pedagogic, predominantly practical issues. Are the Ps fit for purpose? Do they cover all the bases? Is now time for something new? Apart from the oft-made point that the mnemonic is easy to remember, the poesy of the Ps passes many people by.

Poetry, though, benefits from the rhyme-as-reason effect, whereby people are more inclined to believe lines that rhyme and chime in time than those that don't. Hence the popularity of sayings like An Apple a Day Keeps the Doctor Away. Hence the impact of rhyming brand names like FitBit, GoPro, Hubba Bubba, Curly Wurly, Under Armour, Sweaty Betty. Hence the unforgettability of advertising slogans like "J'adore Dior", "Don’t Book It, Thomas Cook It", “You Can’t Fit Quicker Than a Quik-Fit Fitter”, “A Mars a Day Helps You Work, Rest and Play" (Brown and Wijland, 2015).

Our Ps, of course, don't rhyme. However, they are a fine example of alliteration, both with regard to the initial consonant and the internal repetition of "ce" (place, price) and "ro" (product, promotion). ${ }^{7}$ Nowadays, admittedly, alliteration is often associated with tongue-twisters and children's nursery rhymes such as She Sells Sea Shells by the Seashore or the P-fest that is Peter Piper Picked a Peck of Pickled Pepper. The upshot is that alliteration is held in low esteem (Cowdell, 2011). Yet, as Roper (2011) reveals, alliteration is an exceptionally ancient and onceubiquitous literary device, a device that held dominion before rhyming became the norm. The epic poetic form in particular abounds with alliteration, assonance and analogous literary schemes (Wynne, 2016). 
On top of that, the formulation product, price, place, promotion comprises one three-syllable (promotion), one two-syllable (product) and two one-syllable (price, place) words. Taken together, they have a wonderfully rhythmic quality where a trochee is followed by a spondee, which is followed in turn by a dactyl (Williams, 2009). When combined with plosive Ps, which are both propulsive and persuasive, the overall combination accords with the three-beat structure that forms the basis of the western poetic tradition (Baker, 2009). ${ }^{8}$ Or to put it another way, as a line of poetry, the 4Ps scans well, especially when compared to many perfunctory, preposterous, pontifical, purportedly preferable alternatives. Better yet, they make a wonderful refrain, a refrain that poetasters like me can employ with impunity:

Product Place Price Promotion

It's a kind of magic potion

Slap it on like Olay lotion

Product Place Price Promotion

Product Place Price Promotion

Tyro students like the notion

Only scholars want demotion

Product Place Price Promotion

Probably Practically Perfect, Perhaps 
In his bestselling book Win Bigly, Scott Adams (2017) analyses the rhetorical devices employed by Donald Trump in the American presidential election campaign of 2016. A master selfmarketer, Trump's rhetorical acumen was so far ahead of his opponent, says Adams, that Hillary Clinton never stood a chance. Whereas the latter focussed on the minutiae of policy, The Donald relied on classical rhetorical devices: Keep it Simple; Make it Memorable; and, Repeat it Repeatedly.

Marketing's 4Ps ticks all the Trump boxes. It is a weapons-grade rhetorical device, one that "practitioners embrace despite lack of solid evidence" (Constantinides, 2006, p. 432). It is an iconic mnemonic that will continue to captivate, ample alliterative alternatives notwithstanding. It may be the scholarly equivalent of a nursery rhyme, but nursery rhymes linger forever in our memories. That's more than can be said for many academic articles.

Are the 4Ps finished? If you mean finished, as in over and done with, the answer is assuredly no! If you mean finished, as in primped, pimped, polished perfection, the answer is yes, yes, yes indeedy...

\section{Notes}

1. The authors of Bluff Your Way in Marketing, for example, treat the 4Ps as a get-out-of-jail-free card (Harding and Walton 1993). When one's bluff is about to be called, they recommend reverting to an "emergency matrix" containing the peerless foursome, plus packaging and positioning (for luck!).

2. If you manage to read the verses without retching, you'll notice that my P-sequence is slightly different from the "normal" order. When not being mortifyingly forgetful, I've always placed Place second. It sounds slightly more poetic to my admittedly unreliable ear.

3. Casual observation suggests that $\mathrm{C}$ is our principal consonantal alternative to $\mathrm{P}$. Why $\mathrm{C}$ ? Well, the hard $\mathrm{C}$ has long been popular with marketers, as classic brand names like Coca-Cola, Costa Coffee, Calvin Klein and Candy 
Crush Saga attest. C is also paired with P in everyday abbreviations for Politically Correct, Personal Computer, Police Constable, etc. They go together.

4. My working title for this essay was "Are the Four Ps Fucked?" Rhetorically, it's a show-stopper. However, I would have been forced to replace " $u$ " and "c" with asterisks, which undermines its WTF factor. "Finished" is more poetic than the f-bomb, on account of the word's singularly apt double meaning. Forced to choose between poetical and rhetorical power, I opted for the former. My heart lies with the latter, though.

5. The first of these has often been tried. MIXMAP springs to mind (Vignali and Davies 1994). The second and third remain contenders, though pie-charts and Venn-diagrams may be too ubiquitous to trigger a paradigm shift. Another possibility is the marketer-as-artist metaphor posited by Borden (1964). Although the marketing mix is usually viewed through a culinary lens (marketing as cooking, mixing ingredients and so on), Borden also alludes to mixing colours on an artist's palette. Given that the three primary colours are infinitely adaptable; given that some researchers believe marketing is more of an art than a science; and given that visual rhetoric unfailingly trumps verbal rhetoric (Adams 2017), palette may be the $\mathrm{P}$ that precipitates $\mathrm{p}$-mageddon.

6. The thing that surprised me about digital marketers' critiques of the 4Ps is that no one (to my knowledge) suggested the 4Ps of iProduct, iPrice, iPlace, iPromotion. That said, I wouldn't be at all surprised if someone is currently working on working Platform into the foursome.

7. FYI, the technical term for internal alliteration like this is consonance (Williams 2009). Some might suggest that "ce" is sibilance not consonance, but let's not worry about that until "parse" is part of our P-pool.

8. Let's not forget, furthermore, that four is a deeply symbolic number, a magic number that carries connotations of cosmic harmony (Lundy 2005). But don't get me started on magic...

\section{References}

Adams, S. (2017), Win Bigly: Persuasion in a World Where Facts Don't Matter, New York: Portfolio.

Bacon, J. (2017), “The Big Debate: Are the 4Ps of Marketing Still Relevant?”, Marketing Week, February 9, www.marketingweek.com [accessed 18/10/17]

Baker, N. (2009), The Anthologist, New York: Pocket Books.

Bennett, A.R. (1997), “The Five Vs - a Buyer's Perspective of the Marketing Mix”, Marketing Intelligence and Planning, 15 (3), pp. 151-156.

Booms, B.H. and Bitner, M.J. (1981), "Marketing Strategies and Organization Structures for Service Firms", in J.H. Donnelly and W.R. George (eds), Marketing of Services, Chicago: American Marketing Association, pp. 47-51.

Borden, N.H. (1964), "The Concept of the Marketing Mix”, Journal of Advertising Research, 2 (June), pp. 7-12.

Brown, S. (2003), Free Gift Inside, Oxford: Capstone.

Brown, S. and Wijland, R. (2015), "Profit from Poetry: Bards, Brands and Burnished Bottom Lines", Business Horizons, 58 (5), pp. 551-561. 
Chartered Institute of Marketing (2016), 7Ps: A Brief Summary of Marketing and How It Works, Maidenhead: CIM.

Constantinides, E. (2006), "The Marketing Mix Revisited: Towards the $21^{\text {st }}$ Century Marketing," Journal of Marketing Management, 22, pp. 407-438.

Cowdell, P. (2011), "Purposely to Please the Palates of Pretty Prattling Playfellows", in J. Roper (ed), Alliteration in Culture, Basingstoke: Palgrave, pp. 62-73.

Dillon, B. (2017), Essayism, London: Fizcarraldo Editions.

Forrester Research (2009), Adaptive Brand Marketing, Cambridge, MA: Forrester Research Inc.

Goi, C.L. (2009), “A Review of Marketing Mix: 4Ps or More?”, International Journal of Marketing Studies, 1 (1), pp.1-15.

Goldsmith, R.E. (1999), “The Personalised Marketplace: Beyond the 4Ps”, Marketing Intelligence and Planning, 17 (4), pp. 178-185.

Grönroos, C. (1994), “Quo Vadis Marketing? Toward a Relationship Marketing Paradigm”, Journal of Marketing Management, 10 (5), pp. 347-360.

Gummesson, E. (1997), "Relationship Marketing as a Paradigm Shift: Some Conclusions from the 30R Approach", Management Decision, 35 (4), pp. 267-272.

Harding, G. and Walton, P. (1993), Bluff Your Way in Marketing, London: Ravette Books.

Kavanagh, D. (2014), "Restoring Phronesis and Practice: Marketing's Forgotten Ps", Journal of Historical Research in Marketing, 6 (3), pp. 331-350.

Kent, R.A. (1986), "Faith in Four Ps: An Alternative", Journal of Marketing Management, 2 (2), pp. 145-154.

Kotler, P. (2003), Marketing Insights from A to Z, New York: Wiley.

Kotler, P. (2008), FAQs on Marketing: Answered by the Guru of Marketing, London: Marshall Cavendish.

Lauterborn, B. (1990), “New Marketing Litany: Four Ps Passé, C-Words Take Over”, Advertising Age, 61 (41), p. 26.

Lourenço, F. (2016), "Marketing in SMEs: A 4Ps Self-Branding Model”, International Journal of Entrepreneurial Behaviour and Research, 22 (1), pp. 155-174.

Lundy, M. (2005), Sacred Number: The Secret Qualities of Quantities, Glastonbury: Wooden Books. 
McCarthy, E.J. (1960), Basic Marketing: A Managerial Approach, Homewood: Irwin.

Miles, C. (2014), "Rhetoric and the Foundation of the Service-Dominant Logic", Journal of Organizational Change Management, 27 (5), pp. 744-755.

O'Shaughnessy, J. and O'Shaughnessy, N.J. (2009), “The Service-Dominant Perspective: A Backward Step?", European Journal of Marketing, 43 (5-6), pp. 784-793.

Rafiq, M. and Ahmed, P.K. (1995), "Using the 7Ps as a Generic Marketing Mix: An Exploratory Survey of UK and European Marketing Academics", Marketing Intelligence and Planning, 13 (9), pp. 4-15.

Ritson, M. (2009), “Stop This Wordplay”, Marketing Magazine, December 2, p. 20.

Roper, J. (2011), "Introduction: Key Topics in the Study of Alliteration", in J. Roper (ed), Alliteration in Culture, Basingstoke: Palgrave, pp. 1-20.

Sheth, J.N., Gardner, D.M. and Garrett, D.E. (1988), Marketing Theory: Evolution and Evaluation, Wiley: New York.

Sheth, J.N. and Sisodia, R. (2012), The 4 As of Marketing: Creating Value for Customer, Company and Society, New York: Routledge.

van Waterschoot, W. (1999), "The Marketing Mix," in M.J. Baker (ed), The IEBM Encyclopaedia of Marketing, London: Thomson, pp. 317-330.

van Waterschoot, W. and de Haes, J. (2008), "Marketing Mix Metaphorosis: The Heavy Toll of Too Much Popularity," in P.J. Kitchen (ed), Marketing Metaphors and Metamorphosis, Basingstoke: Plagrave, pp. 42-61.

Vargo, S.L. and Lusch, R.F. (2016), "Institutions and Axioms: An Extension and Update of Service-Dominant Logic", Journal of the Academy of Marketing Science, 44 (1), pp. 5-23.

Vignali, C. and Davies, B.J. (1994), "The Marketing Mix Redefined and Mapped: Introducing the MIXMAP Model”, Management Decision, 32 (8), pp. 11-16.

Williams, R. (2009), The Poetry Toolkit, London: Continuum.

Wynne, O. (2016), "Poetic Meter and Form" in J. Martineau (ed), Trivium: The Classical Liberal Arts of Grammar, Logic and Rhetoric, Glastonbury: Wooden Books, pp. 115-171.

Yudelson, J. (1999), “Adapting McCarthy's 4Ps for the Twenty-First Century”, Journal of Marketing Education, 21 (1), p. 60. 


\title{
Why it is High Time for a Renewed Focus on Rhetoric in Marketing
}

\author{
Chris Hackley
}

In this short, somewhat polemical, opinion piece I will suggest that the renewed research focus on the rhetoric of and in marketing signalled by this special issue is both timely and necessary, for two reasons. One is that a greater understanding of rhetorically oriented research in marketing can help to render marketing studies more relevant to current marketing, advertising and branding practices in the age of social media. The other reason, connected to the first, is that marketing research and education serve wider constituencies, and the propagation of a greater understanding of rhetoric can serve the critical education of consumers and citizens.

We seem to be living in an age of pathos in public communication. In both marketing and politics, communication that does not elicit an emotional response is quickly forgotten. Mark Thompson, currently CEO of the New York Times and former Director General of the BBC, argues that advertising and marketing have had a role in the decline of political communication, and that part of the answer is to teach our children rhetoric ${ }^{1}$ to re-awaken the critical understanding of techniques such as parataxis, used by politicians such as Donald Trump. Contemporary marketing, of course, uses visual cues far more than oratory, yet the classical rhetorical concepts remain relevant not only to visual communication but also to the ways in which mediated text and speech are understood.

Of course, it is unrealistic to expect that marketing research and education suddenly adopt classical rhetoric as an informing discipline, and perhaps it is not necessary. The ways in which ethos, pathos, logos and kairos play out in marketing communication may, in any case, require conceptual translation for a mediated age. There have been many studies that examine the techniques of persuasion in marketing, which broadly can be conceived as rhetorical studies, although from many different disciplinary perspectives. If the commonalities of these as rhetorical studies can be acknowledged then perhaps this would constitute a move toward greater recognition not only of the importance and relevance of studies in marketing as rhetoric, but also toward greater understanding of the varieties of rhetoric that manifest in marketing and beyond.

1 https://www.theguardian.com/books/2016/aug/27/from-trump-to-brexit-rhetoric-how-todayspoliticians-have-got-away-with-words accessed 4.3.2018 
The study of marketing rhetoric, then, would benefit from a stronger sense of thematic unity but it is also timely because of the reach of marketing techniques, values and norms into everyday life. Rhetorical studies can then play an important part in the project of critical marketing (Tadajewski and Cluley, 2013). Marketing has played a central role in the perpetuation and legitimation of ideologies of managerialism and corporatism (Marion, 2006) and rhetorically oriented investigation can reveal the techniques, practices and modes of circulation that characterise the spread of ideological communication.

The study of rhetoric has been a marginal pursuit in marketing but it is by no means peripheral to the main business of social science. McCloskey (1983) famously drew attention to the distinction between economic method, and the methods of economic argument, that is, the rhetoric of economics. The manifest shortcomings of economic method, especially in predictive validity, continue to be confounded by the rhetorical force of economic discourse. One might make a similar point about marketing. It has enjoyed immense success as an academic discipline reflecting its enormous presence in contemporary life, in spite of less than universal respect for the scientific validity of its research, or its managerial techniques (Saren, 2000; Wensley, 1995; Willmott, 1995, 1999). McCloskey's (1983) points remain equally salient today for economics but the challenge she set for the social sciences more broadly has been taken up unevenly. Discursive psychology has been one important exception (Billig, 1987,1991; Potter, 1996, 2001) since it addresses the insight that human communication is inherently rhetorical in the broad sense that our utterances, thoughts and conversation have a performative element (Austin, 1962) both to external audiences, and to ourselves as our own audience. Words do things as well as saying things, and we face a need to justify ourselves to ourselves as well as justifying ourselves to others. Indeed, as noted earlier, in some areas of contemporary life, such as political discourse, it often seems that the tone, style and presentation of argument carry greater weight than the content in swaying opinion. The performance of communication, magnified by mediation, exerts such a rhetorical force that the moving parts behind that performance can be obscured. As Mark Thompson points out, the quality of argument in contemporary political discourse seems poor in comparison to earlier times, partly, perhaps, because public sensitivity to rhetorical strategies has been blunted by the flood of marketing and advertising since the 1950 s. 
Marketing has not escaped critical scrutiny of its rhetorical strategies (e.g. Brownlie and Saren, 1992; Hackley, 2001; Tonks, 2002; Miles, 2014a). However, much of the attention to rhetoric in marketing has been diffused across a number of disciplinary foci, including critical discourse studies in marketing (Hackley, 2016; Moufahim et al., 2007; Skålén et al., 2008) postmodernist/poststructuralist approaches to marketing (Brown, 1995) literary analyses of the linguistic tropes, metaphors and rhetorical strategies of marketing (Brown, 2002, 2005; Hackley, 2003; Miles, 2014b) critical analyses of the rhetoric of marketing practice (Brownlie and Saren, 1997; Fischer and Britor, 1994; Nilsson, 2015; Svensson, 2007) studies of propagandistic marketing (O'Shaughnessy, 2016) and of the psychology of persuasion (O'Shaughnessy and O’Shaughnessy, 2004), and, especially, studies of rhetorical aspects of advertising (Moeran, 1985; McQuarrie and Mick, 1999; Scott, 1990, 1994; Stern, 1988, 1990).

This is but a small selection of the rhetorically informed research in marketing, although few of these pieces refer explicitly to classical rhetoric. There seems little doubt that rhetoric is, and indeed should be, a major theme of research in marketing. But there is an opportunity, reflected in this special issue, for much more work. Amongst the issues to be addressed could be how to categorise the scope of rhetorical research in marketing. The few categories above, critical discourse studies, postmodernist/poststructuralist studies, literary analyses, studies of the rhetorical constitution of marketing practice, political marketing and propaganda, and the rhetorical techniques of advertising communication, might be a crude starting point for a retrospective account of the trajectories of influence of rhetorical studies in the field. A second major question might be how and under what conditions to connect the concepts of classical rhetoric with more contemporary frames of research in marketing. Marketing is closely associated with persuasion, and is inherently rhetorical in its communication aspects. A higher profile for the role of rhetoric in marketing can foster better understanding of the rhetorical character of marketing itself, and a better understanding of the foundational concepts of rhetoric and their role in contemporary public discourse in the commercial and other spheres.

\section{References}

Austin, J.L. (1962). How to Do Things with Words. Oxford: Clarendon Press. DOI : $10.1093 /$ acprof:oso/9780198245537.001.0001 
Billig, M. (1987). Arguing and Thinking. Cambridge: Cambridge University Press.

Billig, M. (1991). Ideology and Opinions. London: Sage

Brown, S. (2002). Reading Wroe: on the biopoetics of Alderson's functionalism, Marketing Theory, 2(3), 243-271.

Brown, S. (1995). Postmodern Marketing. London: ITBP.

Brown, S. (2005). Writing Marketing- Literary Lessons from Academic Authorities. London: Sage.

Brownlie, D. and Saren, M. (1992). The Four Ps of the Marketing Concept: Prescriptive, Polemical, Permanent and Problematical. European Journal of Marketing, 26(4), 34-47 https://doi.org/10.1108/03090569210012408

Brownlie, D. and Saren, M. (1997). Beyond the one-dimensional marketing manager: the discourse of theory, practice and relevance. International Journal of Research in Marketing, 14(2), 146-61.

Fischer, E. and Britor, J. (1994). A feminist poststructuralist analysis of the rhetoric of marketing 'relationships'. International Journal of Research in Marketing, 11(4), 317-31.

Hackley, C. (2016). Marketing Texts. In Mautner, G. Discourse and Management_(with contributions from Nick Ellis, Chris Hackley, Cliff Oswick and Ruth Wodak). Palgrave Critical Management Studies. London: Palgrave Macmillan, pp159-168.

Hackley, C. (2001). Marketing and Social Construction: exploring the rhetorics of managed consumption. London: Routledge.

Hackley, C. (2003). "We Are All Customers Now ...” Rhetorical Strategy and Ideological Control in Marketing Management Texts. Journal of Management Studies, 40(5), 1325-1352. http://dx.doi.org/10.1111/1467-6486.00382 
McCloskey, D. (1983). The Rhetoric of Economics. Journal of Economic Literature, 21, 481517.

McQuarrie, Edward F., and Mick, David Glen (1999). Visual rhetoric in Advertising: Textinterpretive, experimental, and reader-response analyses. Journal of Consumer Research, 26(1), 37-54. DOI: 10.1086/209549.

Miles, C. (2014a). Rhetoric and the foundation of the Service-Dominant Logic. Journal of Organizational Change Management, 27(5), 744-755. http://dx.doi.org/10.1108/JOCM-092014-0171

Miles, C. (2014b). The rhetoric of managed contagion: Metaphor and agency in the discourse of viral marketing. Marketing Theory, 14(1), 3-18. http://dx.doi.org/0.1177/1470593113506433

Moeran, B. (1985). When the poetics of advertising becomes the advertising of poetics: Syntactical and semantic parallelism in English and Japanese advertising. Language and Communication, 5(1), 29-44. DOI: 10.1016/0271-5309(85)90017-5.

Moufahim, M., Humphreys, M., Mitussis, D., \& Fitchett, J. (2007). Interpreting discourse: a critical discourse analysis of the marketing of an extreme right party. Journal of Marketing Management, 23(5), 537-558. http://dx.doi.org/10.1362/026725707X212829

Nilsson, T. (2015). Rhetorical Business: A study of marketing work in the spirit of contradiction. Lund: Lund University.

O’Shaugnessy, N. J. (2016). Selling Hitler: Propaganda and the Nazi Brand. London: Hurst.

O’Shaughnessy, J. \& O’Shaughnessy, N. (2004). Persuasion in Advertising. London: Routledge.

Potter, J. (1996). Representing Reality. London: Sage.

Potter, J. (2001). Wittgenstein and Austin. In M. Wetherell, S. Taylor and S.J. Yates (eds), Discourse Theory and Practice. London: Sage. 
Saren, M. (2000). Marketing Theory. In M. J. Baker (ed), IEBM Encyclopaedia of Marketing, London: International Thomson, 794-809.

Scott, Linda M. (1990). Understanding Jingles and needledrop: A rhetorical approach to music in advertising. Journal of Consumer Research, 17(2), 223-236. DOI: /10.1086/208552

Scott, L. M. (1994). Images in advertising: The need for a theory of visual rhetoric. Journal of Consumer Research, 21(2), 252-273. http://dx.doi.org/10.1086/209396

Stern, B. B. (1988). Medieval allegory: Roots of advertising strategy for the mass market. Journal of Marketing, 52(3), 84-94.

Stern, B. B. (1990). Other-speak: classical allegory and contemporary advertising. Journal of Advertising, 19(3), 14-26. http://dx.doi.org/10.1080/00913367.1990.10673189

Skålén, P., Fougere, M. and Fellesson, M. (2008). Marketing Discourse: A Critical Perspective. London: Routledge.

Svensson, S. (2007). Producing marketing: towards a social-phenomenology of marketing work. Marketing Theory 7(3), 271-290.

Tadajewski, M. and Cluley, R. (Eds) (2013). New Directions in Critical Marketing Studies. London: Sage.

Tonks, D. (2002). Marketing as Cooking: The Return of the Sophists. Journal of Marketing Management, 18(7-8), 803-822. http://dx.doi.org/10.1362/0267257022780660

Wensley, R. (1995). A Critical Review of Research in Marketing. British Journal of Management, 6(1), S63-S82.

Willmott, H. (1993). Paradoxes of Marketing: some critical reflections. In Brownlie, D. et al (Eds), Rethinking Marketing. Coventry: Warwick Business School Research Bureau, 207-21. 
Willmott, H. (1999). On the idolization of markets and the denigration of marketers: some critical reflections on a professional paradox. In Brownlie, D., Saren, M., Wensley, R., Whittington, R. (Eds), Rethinking Marketing. London: Sage. 


\title{
Rhetoric and the Inductive Realist Model of Theory Generation:
}

\author{
The Case of Resource-Advantage (R-A) Theory
}

\author{
Shelby D. Hunt
}

With the development of the "inductive realist model of theory generation" (Hunt, 2013), the philosophy of marketing science has taken steps to link what has historically been considered to be two distinctly different "contexts" in marketing theory. That is, the inductive realist model of theory generation shows how processes in the "context of discovery" in science (e.g., developing new theories) are linked to processes in the "context of justification" (e.g., empirically testing theories to provide epistemic warrant for theories' truth-content). Specifically, building on the inductive realist model of theory status (Hunt, 2012), the inductive realist model of theory generation shows that discovery and justification processes are linked in that empirical successes and failures play an important role in both. Furthermore, they are linked because both processes are constrained and closely reasoned according to scholars' background knowledge and their discipline's norms. Moreover, the model links discovery and justification in that the world external to the theorist is prominent in both processes. Like the inductive realist model of theory status, the inductive realist model of theory generation assumes the standard, scientific realist positions that (1) the world exists independently of its being perceived, (2) the purpose of science is to develop theories that increase our understanding of the external world through systematized structures capable of explaining and predicting phenomena, and (3) the best, if not the only, 
explanation of the enormous success of science in explaining and predicting phenomena since science's inception in the mid-1500s is that science produces theories that are "approximately" true (Hunt, 2012; Putnam 1975).

If the inductive realist model of theory generation can link discovery and justification processes, what about rhetorical processes? In explicating rhetorical processes, Tonks $(2002$, p.807) points out that, although there are diverse ways in which "rhetoric" is used in various literatures, it most often seems to imply "bending the truth for the purposes of guile, deceit, subterfuge, dishonesty, coercion, and so on." In contrast, tracing his preferred position to that of Aristotle, Tonks (2002, p. 808) argues that marketing should define rhetoric as "the faculty of discovering in the particular case what are the available means of persuasion.” Relying on Tonks' (2002) construal of rhetoric, this essay argues that the inductive realist model of theory generation incorporates rhetorical processes.

Two decades ago, Maki (1988) noted that many advocates of rhetorical analysis in the economics discipline seemed to be construing the acceptance of rhetorical analysis with the rejection of "world realism and truth realism." He systematically analyzed the relationship between rhetoric and realism in economics, and he argued for their compatibility:

Is marketing rhetoric [to economists] with explicit anti-realism good rhetoric, that is, does it [successfully] persuade the audience of economists? ... The message of rhetoric will be - and already has been - objected to by some audiences precisely because of the accompanying anti-realism. These audiences do not buy rhetoric because they (incorrectly) believe that by so doing they would have to give up realism. There are arguments against [world and truth] realism that have to be taken seriously [e.g., what does "approximately true" mean?], but the idea of the rhetorical character of communicative practice in economics is not inherent to any one among them. (Maki, 1988, p.107-8) 
Like the message of Maki (1988) in economics, this essay argues that rhetorical analysis and realism in marketing science are compatible. I begin my argument by providing a succinct overview of the inductive realist model of theory generation. Then, I show where in the model rhetoric plays a major role. Finally, as a concrete example, I discuss certain aspects of the rhetorical strategies used in the development of the original resource-advantage (R-A) theory article, that is, Hunt and Morgan (1995).

\section{The Inductive Realist Model of Theory Generation}

The inductive realist model of theory generation, shown in Figure 1, proposes that the impetus for theory generation is problem recognition (Box 2). The model highlights three kinds of important disciplinary problems: unexplained phenomena, empirical problems, and conceptual problems. Empirical problems are those that stem from the empirical failures (Box 10) of a discipline's current theories. Because theories are used to explain phenomena, predict phenomena, and guide interventions, as shown in Box 5, empirical problems result from the failures of extant theories to explain phenomena well, to predict phenomena accurately, and to guide interventions successfully in the external world (Box 6). Conceptual problems are those that result from an extant theory's lack of conceptual "fit." The lack of fit may be internal, as when a theory's internal logic is inconsistent, or external, as when a theory conflicts with other, well-accepted theories.

\section{<<Insert Figure 1 About Here >}

Both problem recognition (Box 2) and the creative cognitive acts (Box 3) that lead to new theory proposals (Box 4) involve constraints (Box 7) and reasoning processes (Box 8). That is, how scholars perceive or define what constitutes a problem for their research to address is constrained 
by the scholars' background knowledge, including the state of their discipline's current knowledge (Box 1). It takes creative cognitive acts (Box 3) to go from problem recognition to new theory proposals (Box 4). As to creativity, the model stresses that the creative cognitive acts involved in theory generation take place through time. Also, note that the concept in Box 3 is labeled "creative cognitive acts," not a "creative cognitive leap." Although "leap" is often used in the theory-generation literature, it wrongly tends to imply that discoveries occur "all at once" from a single flash of insight. Instead, the model views discoveries as most commonly resulting from a series of important insights that take place through time-a series of ahas!

After a scholar recognizes a problem to be addressed (Box 2) and engages in the creative, constrained, reasoning process of problem solving by means of generating new theory (Box 3), the scholar must choose (or find) an appropriate publication outlet for the proposed new theory (Box 4). When manuscripts are developed for possible publication in academic journals, the inductive realist model specifically recognizes that the manuscript development process is creative, constrained, and highly reasoned.

During the manuscript development process, theory proposals are often modified. The modifications often come from performing the very act of developing epistemic warrant for the truth-content of the new theory proposal. The epistemic warrant consists of the theoretical and empirical evidence for the proposed theory. Also, many changes in the theory result from suggestions or directives from reviewers and editors. The norms of reviewers and editors constitute constraints that authors of new theory proposals must work within (Box 7). Satisfying the constraints imposed by reviewers and editors involves detailed reasoning processes (Box 8).

\section{Rhetoric's Place in the Model}


Rhetoric, considering and developing communication strategies that will (hopefully) be successful, plays a central role in Box 4. (Unpublished manuscripts are, by definition, academically unsuccessful.) As manuscripts are developed that explicate the new theory, scholars must consider the "target market" for their works. The primary target market is not the readers of a particular journal; it is the journal's reviewers and editors. Ideally, reviewers would read manuscripts carefully and evaluate each paper's strengths and weaknesses according to the norms of the discipline and the specific journal. However, it is well known that most reviewers look primarily at a paper's weaknesses, not its strengths. That is, reviewers focus on quickly and easily finding reasons to reject manuscripts.

Therefore, the primary rhetorical task of an author should not be viewed as arguing for an article's acceptance. Rather, the rhetorical task of an author is to develop carefully the kinds of arguments for the proposed work that will persuade reviewers not to reject the work outright. Good rhetorical strategy requires authors to anticipate reviewers' potential rejection-reasons and then to counter-argue those reasons in the original manuscript and subsequent revisions. Only when reviewers are convinced that no "fatal flaw" exists do they consider seriously a paper's strengths.

As a case in point, consider the rhetoric of the original article that proposed what has come to be referred to as the "resource-advantage (R-A) theory of competition" (Hunt and Morgan 1995). The example is appropriate because, first, it has been, by all customary, academic metrics, highly successful (e.g., as of this writing, it has over 3000 Google Scholar citations). Second, of the four reviewers of the original manuscript, only one strongly favored accepting a (modestly revised) version of the article, whereas two were decidedly mixed in their reviews, and the fourth reviewer thought the article was, essentially, unacceptable. Third, I can personally testify as to 
the rejection-arguments that Rob and I anticipated in the original submission and how we attempted to counter those arguments.

\section{The Development of Resource-Advantage (R-A) Theory}

In the spring of 1994, Robert Morgan suggested that we coauthor an article based on the "resource-based" theory of strategy that was being developed in the strategic management literature. This literature suggested that strategy had been misguided by adopting "industry" as the central focus of strategy development. These new authors were arguing that managers should focus on developing and acquiring rare, valuable, and inimitable resources as a means for achieving "rents," that is, profits in excess of those achieved by a firm under the conditions of perfect competition. The problem (see Box 2) that Robert and I recognized was that the existing literature had (we thought) poorly conceptualized the nature of firms' "resources." The original article that we considered writing would develop a new schema for categorizing the various kinds of resources that firms might have. Indeed, we prepared a detailed outline of the structure of the proposed article (see Box 3).

As part of our review, we came across an article by Conner (1991), in which she argued that any theory of the firm should be able to explain the reasons for the existence of firms and the factors that limit their sizes and scopes. Furthermore, she argued, the resource-based theory of strategy's focus on heterogeneous, imperfectly mobile resources, constituted the beginnings of a new theory of the firm. We found her arguments to be highly persuasive. However, Rob and I came jointly to two realizations. First, the resource-based theory of the firm was strongly within the confines of the neoclassical theory of perfect competition, which we viewed to be problematic (see Box 2). Second, if we were to join the emerging, resource-based theory of the firm with heterogeneous demand theory and Alderson's $(1957,1965)$ theory of differential advantage, we 
might be able to develop a new theory of competition. It was definitely an aha! moment — one of a series of ahas! in our endeavors to develop R-A theory (see Box 3).

\section{Developing Hunt and Morgan (1995)}

After several months of research, we developed a manuscript on the proposed new theory and targeted it to the Journal of Marketing. The original submission had several key contributions to the literature (i.e., several "strengths"). First, it defined "resources" as those tangible or intangible entities that were available to firms that enabled them to produce, efficiently and/or effectively, market offerings that had value to some market segment(s). Second, it provided a set of foundational premises for the new theory of competition that were contrasted with neoclassical, perfect completion theory. Third, it provided a key diagnostic tool for understanding competitive advantage, which we labeled the "competitive position matrix." Fourth, it distinguished between two very different kinds of advantages: a firm's comparative advantages in resources and a firm's marketplace positions of competitive advantage. Fifth, it theorized that it is firms' comparative advantages in resources that lead to marketplace positions of competitive advantage, which in turn, lead to superior financial performance. Sixth, it used the new theory, with its focus on heterogeneous, imperfectly mobile resources, to explain firm diversity. Seventh, it used the new theory to contribute to explaining the differences in abundance, innovation, and quality that had been observed between market-based and command economies. Eighth, it explored the issue of whether a firm's market-orientation can be a resource that can lead to sustained, superior financial performance.

When Rob Morgan and I were working on the original manuscript, we realized that the paper's strengths did not assure its acceptance. Therefore, we tried to anticipate the reasons that reviewers might give for rejecting it, and we incorporated arguments that might persuasively 
counter the objections. In doing so, a constraint (Box 7) was that the arguments must be truthful, for our personal moral codes did not permit disingenuous argumentation. The following are five rejection-reasons that we anticipated:

1. This paper is not marketing; it belongs in an economics journal.

2. The paper does not have enough "contribution" for a major journal.

3. The article unfairly and inaccurately characterizes neoclassical economics and the premises of perfect competition theory.

4. R-A theory's premises are not a descriptively accurate characterization of the actual process of competition.

5. The theory is not expressed as a mathematical model.

As to \#1, we were much concerned that reviewers would reject the article because it was supposedly not "marketing." Therefore, we added the long section of the article that focused on market orientation. No reviewer, we believed, could possibly argue that an article with so much analysis of market orientation was not a marketing article. We were successful; no reviewer did so argue. As to \#2, a second reason for adding the "market orientation" section was to increase the article's “contribution.” It, too, was successful; no reviewer complained of "lack of contribution." However, one reviewer insisted that the market orientation portion of the original submission should be dropped and developed as a totally separate article. (We successfully argued against this suggestion in a revision.)

As to \#3, Rob and I spent much time and effort trying to ensure that we were fairly and accurately presenting neoclassical theory, and we had others check it for accuracy. As a result, no reviewer faulted our presentation of neoclassical theory in the original submission. Indeed, in the many follow-up articles that have further developed and applied R-A theory, no reviewer has ever faulted us on this issue. As to \#4, much to our surprise, no reviewer either challenged the descriptive adequacy of our theory's premises or suggested modifications. (Readers should note 
that premise 9 was dropped as unnecessary in subsequent articles developing the theory, and premise 10 was modified. However, neither change resulted from comments by any reviewer of any article.)

As to \#5, Rob and I could see no way that the theory could be expressed as a set of equations. Therefore, in the original article, we "finessed" the issue by not discussing it. No reviewer criticized the theory on the grounds that it was not developed in the language of mathematics. (However, R-A theory's lack of equations has been a problem for getting articles on R-A theory accepted in other journals.)

Given the overall success of our rhetorical strategy, what were reviewers' major objections? Four rejection-reasons were unanticipated and had to be addressed in revisions. First, two reviewers insisted that comparing R-A theory to perfect competition theory was inappropriate because perfect competition theory was a "straw-man" rival. Readers should see the third paragraph of the introduction for how we attempted to argue against this view. Second, a reviewer was adamant that our article should provide a detailed review of all the numerous, previously published critiques of neoclassical theory. Readers should see the fourth paragraph of the introduction for how we attempted to argue against this view.

Third, a reviewer was highly critical that our theory did not use the work of Dickson (1992) as the primary starting point for our theory. We argued that (1) we had cited Dickson (1992), but (2) our theory was not a simple extension of that work, and (3) there was no way to turn the article into such an extension. The editor, but not the reviewer, found our arguments persuasive.

Fourth, a reviewer maintained that the original article did not accurately characterize transaction cost economics. Although Rob and I believed our discussion of transaction cost economics was 
accurate, we rephrased our discussion of transaction cost economics in a manner that we believed would be both truthful and would satisfy the reviewer. See the second complete paragraph in the "Summary Evaluation" section of the article for our revised wording regarding transaction cost economics.

After two revisions of the article, the editor accepted it in December, 1994. Would it have been accepted if Rob and I had not explicitly considered the rhetoric of the article? Perhaps it would have, but I believe that the rhetoric we employed definitely increased its likelihood of acceptance.

\section{Conclusion}

The explicit consideration of rhetoric contributes to both marketing theory and research. Furthermore, as the previous discussion shows, the inductive realist model of theory generation not only links discovery processes with justification processes in marketing science, but it also incorporates rhetorical processes.

As a final note, this article's example is a "first person" rhetorical analysis of the use of arguments in the publication of the Hunt and Morgan (1995) article. However, most rhetorical analyses are "third person" analyses. That is, most rhetorical analyses are one scholar's interpretation of other scholars' works. Accordingly, I urge users of rhetorical analysis to adopt the "principle of charity of interpretation" from the philosophy of science (Davidson, 2001).

Roughly, the principle of charity of interpretation maintains that when one interprets the works of others one should (1) assign meanings to others' words so as to maximize the overall sensemaking and truth-content of others' claims and (2) assume that the motivations underlying the rhetoric of others' works are principled. Adopting the principle of charity of interpretation, I 
argue, will not only further the cause of promoting the acceptability of rhetorical analysis in marketing scholarship, but it will also further the contributions of rhetorical analysis to marketing scholarship. In short, adopting the principle of charity of interpretation is good rhetoric.

\section{References}

Alderson, W. (1957). Marketing behavior and executive action. Homewood, IL: Richard D. Irwin.

Conner, K. (1991). A historical comparison of resource-based theory and five schools of thought within industrial-organization economics: do we have a new theory of the firm? Journal of Management, 17(March): 121-154.

Davidson, D. (2001). Inquiries into truth and interpretation. Oxford: Oxford University Press.

Dickson, P. R. (1992). Toward a general theory of competitive rationality. Journal of Marketing, 56 (January): 69-83.

Hunt, S. D. (2012). Explaining empirically successful marketing theories: the inductive realist model, approximate truth, and market orientation. Journal of the Academy of Marketing Science, 2(1): 5-18.

Hunt, S. D. (2013). The inductive realist model of theory generation: Explaining the development of a theory of marketing ethics. AMS Review 3(2): 61-74.

Hunt, S. D. \& Morgan, R. M. (1995). The comparative advantage theory of competition," Journal of Marketing, 59 (April): 1-15.

Maki, U. (1988). How to combine rhetoric and realism in the methodology of economics. Economics and Philosophy, 4(1): 89-109.

Putnam, H. (1975). Mathematics, matter and method. Cambridge: Cambridge University Press.

Tonks, D. (2002). Marketing as cooking: The return of the sophists. Journal of Marketing Management, 18(7/8): 37-41. 


\title{
Reputation Marketing:
}

\section{Isocrates, Ethos, and Indirect Reciprocity}

\author{
Charles Marsh
}

More so than its rivals in classical Athens, Isocratean rhetoric focused on the power and importance of established reputation. In that period, Isocrates and his school competed first with Plato's Academy and, later, with Aristotle's Lyceum: "In Greece in the fourth century B.C.," historian Donald Clark (1957) summarizes, "there was a three-cornered quarrel among the leading teachers concerning what it takes to make a successful speaker" (p. 5).

Very interesting (I hope) - but, more than two millennia later, what can the quirks of Isocratean rhetoric mean for us? At least three things:

6. First, Isocratean rhetoric and the school built around it were far more successful than the competing models offered by Plato and Aristotle.

7. Second, Isocratean rhetoric was built on the power of a speaker's established, enduring reputation, a form of ethos.

8. Third, evolutionary biologists in recent decades have, via a concept termed indirect reciprocity, confirmed the effectiveness of Isocrates' approach to building reputation as 
well as its deep-rooted biological foundations.

This article will document these three claims in hopes of strengthening the resource-gathering effectiveness of modern marketing programs - and, inseparably, their charitable/reputationbuilding impulses.

\section{The Success of Isocratean Rhetoric}

After describing the "three-cornered" rivalry in classical Athens, Clark (1957) continues, "From this quarrel Isocrates (436-338 BC) came out triumphant.... For forty years Isocrates was the most influential teacher in Athens" (pp. 5, 58). Attracting students from throughout the Hellenic world, Isocrates built the largest and most financially successful of the three schools (Marsh, 2013). In oratorical contests sponsored by the relentlessly competitive Greeks, his students triumphed (Jebb, 1876). In contrast, “most” of Plato’s students, Jaeger (1944) laments, “were characterized by their inability to do any real service" to the state (p. 137). Jebb (1876) has a similarly bleak assessment of the rhetorical success of Aristotle's students: "The school of Aristotle ... produced not a single orator of note except Demetrios Phalereus" (p. 431). The later Roman rhetoricians Cicero and Quintilian consistently preferred Isocratean rhetoric to its Platonic and Aristotelian counterparts (Marsh, 2013). "On the whole," concludes Henri Marrou (trans. 1956/1982) in A History of Education in Antiquity, "it was Isocrates ... who educated fourth-century Greece and subsequently the Hellenistic and Roman worlds” (p. 79). 


\section{Ethos and Reputation in Isocratean Rhetoric}

Isocrates, Plato, and Aristotle had profoundly different concepts of ethos, or the persuasive value of a speaker's character. Plato (trans. 1930/1989) believed that the only acceptable form of rhetoric was delivered by philosophers who had, through dialectic, reasoned their way into “eternal and unchanging" concepts that resided within some kind of divine consciousness (484B). Armed with such absolute knowledge, the enlightened philosopher - ideally, Plato's Philosopher King - could craft whatever sort of reputation would quell dissent and lead lesser mortals to as much of the divine truth as they could understand. In Republic, for example, Plato details instances in which Philosopher Kings can trick their subjects (459D; 460A) and even lie to them (459C).

For Aristotle (trans. 1954), ethos was, in general, more powerful than the related persuasive concepts of logos and pathos (1356a), but it also was situational. For Aristotle, a rhetorician's ethos-related reputation was constructed during and within the speech - "not by what people think of his character before he begins to speak" (1356a). Aristotelian ethos thus may be at odds with a speaker's true, enduring character: "He should be thought to entertain the right feelings" (1377b, emphasis added). Scholars have offered various explanations for how a rhetorician (or, for our purposes, a marketer) might bamboozle target audiences/markets in this manner (Garver, 1994; Marsh, 2006) - but the venerable George Kennedy (1996), Paddison Professor of Classics, Emeritus, at the University of North Carolina, surely speaks for many in asserting, "Perhaps the most conspicuous lack in the Rhetoric, given Aristotle's own conception of the subject, is its failure to take account of the role in rhetoric of the authority and prestige of the speaker" ( $\mathrm{p}$. 
182).

In comparison with his contemporaries, Isocrates offered a radically different concept of building reputation. Unlike Plato, he believes that absolute certainty on anything is impossible (Antidosis, trans. 1929/1992, 276) - and so out the window go the arrogance and deceptive machinations of the Philosopher King. Unlike Aristotle, he believes that a rhetorician's known, enduring reputation is far more powerful than a situational status built within a single communicative act: “The argument which is made by a man's life is of more weight than that which is furnished by words" (Antidosis, trans. 1929/1992, 278). For this most-effective form of classical rhetoric, then, the question becomes how we build the type of life that generates such ethos. In his 30 surviving essays and letters, Isocrates offers a clear answer that ultimately leads to the modern description of indirect reciprocity.

Throughout his canon, Isocrates consistently advocates two related virtues: moderation and justice (Marsh, 2013), both of which, ideally, lead to personal success by addressing the needs of others. For moderation, Isocrates generally used the Greek word sophrosyne, which included the idea of self-control. In Isocratean rhetoric, sophrosyne means, within relationships, not taking more than you need, particularly when you have the power to do so: "There is satiety in all things.... Refrain when you have your fair share" (To Demonicus, trans. 1928/1991, 20, 38). Isocrates' concept of justice (dikaiosyne) builds upon sophrosyne: It approaches an idea inherent in many global religions and philosophies - Treat others as you would wish them to treat you but extends that idea into treating others (second parties) as you would wish still others (third parties) to treat you. In Nicocles (trans. 1928/1991), for example, Isocrates writes, "You should be such in your dealings with others as you expect me to be in my dealings with you" (49). In Plataicus (trans. 1945/1986), he urges Athenians to help a group that cannot reciprocate, 
knowing that the action would win the admiration of observant third parties. This extended form of justice - of Party A helping an in-need Party B, with reciprocation coming from observing Parties $\mathrm{C}$ - approaches the modern concept of indirect reciprocity. Without any biological explanations, Isocrates simply knew that empirical evidence showed that such behavior created positive reputation and consequent resource acquisition (On the Peace, trans. 1929/1982, 32).

Beginning in the final decades of the $20^{\text {th }}$ century, evolutionary biologists began to document and call attention to this same practice of winning through seemingly selfless generosity.

\section{Indirect Reciprocity and Reputation}

Biologist Richard Alexander coined the term indirect reciprocity to contrast with direct reciprocity, in which Party B directly rewards or punishes Party A because A had earlier done so for B. In indirect reciprocity, "the return is expected from someone other than the recipient of the beneficence" - some third party who became aware of A's behavior (Alexander, 1987, p. 85). “Indirect reciprocity involves reputation and status," Alexander (1987) continues (p. 85). Evolutionary biologists such as Martin Nowak and his colleagues have demonstrated the pervasiveness and power of indirect reciprocity through repeated game-theory and humansubjects experiments (Nowak \& Highfield, 2011). So compelling are their results that Richard Dawkins (2006), author of The Selfish Gene, added a chapter titled "Nice Guys Finish First" to the second edition of that work and, in the third edition, conceded that a more accurate title for his book might have been The Cooperative Gene.

The rewards of indirect reciprocity are so significant that Nowak, Dawkins, and others conclude that it has become basic, genetic human nature (Dawkins, 2006; Nowak \& Highfield, 2011). But does such behavior actually translate to competitive markets? The answer is a resounding yes: A 
study of indirect reciprocity experiments conducted by economists from 2000 through 2016 (Marsh, 2017) found these particular areas of strong agreement:

1. Indirect reciprocity exists: It is pervasive, powerful, and measureable.

2. Indirect reciprocity can be mixed-motive, fusing basic social instinct and strategic, rewards-based thinking.

3. Reputation management is inherent in indirect reciprocity.

4. Indirect reciprocity can be negative, involving punishment.

5. Indirect reciprocity can survive misinterpretations of reputation.

\section{Conclusion: Indirect Reciprocity and Marketing}

Marketing research has made only tentative steps toward acknowledging, by name, indirect reciprocity and incorporating it, particularly with new findings from evolutionary biology and economics, into marketing studies and strategies. Palmer's 2000 study of indirect reciprocity in the European Journal of Marketing posits four well-researched propositions on the possible role of indirect reciprocity in successful marketing campaigns - but database searches of "indirect reciprocity" as part of a title or as a keyword in the articles of top marketing journals indicate a lack of follow-up on that solid beginning. At the very least, examining and, perhaps, defending the potential of cause-marketing programs through the lens of indirect reciprocity would seem to be a promising direction.

As a means of clarifying a brand's ideal position, marketers often champion the idea of a brand mantra - a concise, memorable expression of a key strategic idea (Kotler \& Keller, 2016). Though a bit wordy for the purpose, this recommendation from Pulitzer Prize-winning evolutionary biologist Edward O. Wilson (2012) offers a mantra for incorporating indirect 
reciprocity into modern marketing: "It is also helpful to enhance reputation by what researchers have called indirect reciprocity.... Do good and talk about it. Doors are then opened and opportunities for friendships and alliances increased" (p. 249).

\section{References}

Alexander, R.D. (1987). The biology of moral systems. New York, NY: Aldine De Gruyter.

Aristotle. (1954). The rhetoric and the poetics of Aristotle. (W.R. Roberts \& I. Bywater, Trans.). New York, NY: The Modern Library.

Clark, D.L. (1957). Rhetoric in Greco-Roman education. Morningside Heights, NY: Columbia University Press.

Dawkins, R. (2006). The selfish gene: 30th anniversary edition. Oxford, England: Oxford University Press.

Garver, E. (1994). Aristotle's Rhetoric. Chicago, IL: University of Chicago Press.

Isocrates. (1991). Isocrates, Vol. I. (G. Norlin, Ed. \& Trans.). Cambridge, MA: Harvard University Press. (Original work published 1928)

Isocrates. (1992). Isocrates, Vol. II. (G. Norlin, Ed. \& Trans.). Cambridge, MA: Harvard University Press. (Original work published 1929)

Isocrates. (1986). Isocrates, Vol. III. (L. Van Hook, Ed. \& Trans.). Cambridge, MA: Harvard University Press. (Original work published 1945)

Jaeger, W. (1944). Paideia: The ideals of Greek culture: Vol. III. (G. Highet, Trans.). New York, NY: Oxford University Press.

Jebb, R.C. (1876). The Attic orators from Antiphon to Isaeos. London, England: Macmillan and Company.

Kennedy, G.A. (1996). Reworking Aristotle's Rhetoric. In C.L. Johnstone (Ed.), Theory, text, context (169-184). Albany, NY: State University of New York Press.

Kotler, P., \& Keller, K.L. (2016). Marketing management (15th ed.). Boston, MA: Pearson.

Marrou, H.I. (1982). A history of education in antiquity. (G. Lamb, Trans.). Madison, WI:

University of Wisconsin Press. (Original work published 1956) 
Marsh, C. (2006). Aristotelian ethos and the new orality. Journal of Mass Media Ethics, 21, 338352.

Marsh, C. (2013). Classical rhetoric and modern public relations: An Isocratean model. New York, NY: Routledge.

Marsh, C. (2017). An interdisciplinary case for indirect reciprocity. Paper presented at the meeting of the Barcelona International Critical PR Conference \#7, Barcelona, Spain.

Palmer, A. (2000). Co-operation and competition: A Darwinian synthesis of relationship marketing. European Journal of Marketing, 34, 687-704.

Nowak, M.A., \& Highfield, R. (2011). SuperCooperators: Altruism, evolution, and why we need each other to succeed. New York, NY: Free Press.

Plato (1989). Republic. (P. Shorey, Trans.). In E. Hamilton \& H. Cairns (Eds.), Plato: Collected dialogues (pp. 575-844). Princeton, NJ: Princeton University Press. (Original work published 1930)

Wilson, E.O. (2012). The social conquest of Earth. New York, NY: Liveright.

\title{
Political Marketing: Throwing Away the Script? Donald Trump and the New Age of Rhetoric
}

\author{
Nicholas O’Shaughnessy
}

\section{A Defence of Political Marketing Theory}


Political marketing 'is essentially an interdisciplinary subject of marketing and political science: taking the explanandum from politics and the explanans from marketing theory' (Henneberg, 2002). The normative paradigm of political marketing management is instrumentalist and is a direct translation from the consumer orientation of product - market situations. The essence of the idea of political marketing is very simple: you determine what the people want and give it them. This is attractive in several ways. Firstly it seems to represent some kind of democratic essentialism, for 'the people' are positioned as firmly in the driving seat: more than sovereignty of the majority it represents, seemingly, the dictatorship of the majority. Secondly it is superficially an easy thing to do, all you need are sophisticated tools of market research to define what 'they' want, make the relevant trade-offs and offer them a package.

So the practice is a rationalist - instrumentalist model: conceptually then the political realm is presented as primarily an exchange -based relationship. Political marketing concepts and theories thus evolve from consumer marketing theory and practice. Sheth, Gardner and Garrett (1988) posited twelve schools of consumer marketing derived mainly from social exchange theory or micro economical theory or institutional political economy, where the consumer is the focus and firms compete to satisfy consumer demand as determined via market research (see for example sponsors of the 'MOP', Market-Oriented Party, model; Lees-Marshment, 2001).

While the idea of political marketing has significant limitations (discussed below), strong arguments have been made in defence of this conceptualization. Thus the theory, which this author summarized thus: "Political marketing is useful in our view because political offers do function at some level as 'service', which we would define as that amalgam of party (brand), 
politician (tangible characteristics) and policy promises, (core service offering) and the received, publicly understood history of all three" (Henneberg and O'Shaughnessy, 2007).

And, derivative from the theory, is the practice, as for example under Bill Clinton. Here the marketing research -derived techniques of focus groups and public opinion research, i.e. polling, were the crutch on which his government rested: every major decision, each policy announcement, was framed according to their diktat (Johnson, 2001). According to Dick Morris, Clinton "poll[ed] as often as he breath[ed]" (1997). Clinton advertising was formed via a feedback loop incorporating mall kiosks and visual rough cuts and pre-prepared images (hostile advertisements were also created and tested so that rebuttals could be constructed). Johnson (2001) conceived polling as the "central nervous system" of the modern campaign with the pollster and consultant and manager as its strategic intelligence. And as with Clinton so with Tony Blair: 'New' Labour plagiarized Clintonian techniques of populist governance.

\section{Did Donald Trump Have a Political Marketing Strategy?}

Trump did, by default, have a political marketing strategy- but one of a completely unorthodox kind. The Trump candidacy could be viewed in marketing terms as an outsider strategy, where a revolutionary new product with untested claims gatecrashes its way onto the market at a time when people are simply bored by the rival products' blandness and failure to innovate. This would make Donald Trump the Ryanair of American politics. His is the anti-politics of norm rejection and in marketing terms this would represent a strategy of differentiation via attentiongetting. Just as Ryanair always find a marketing gimmick in being maximally offensive, especially about its rivals, so can Trump. Ryanair has a unique selling proposition (it is cheap), 
but so in a sense has Trump, who is often described as a nativist. But 'nativism' is, apparently, a popular market -oriented appeal to-day in the US.

The marketing approach is tactical not strategic, and that tactic is the offer of a panacea. The Trump 'product' or core marketing offer is of a quick fix- of daring, essentialist solutions: build a wall, eject eleven million migrants, stop migration from selective Islamic countries. This resonates: it is ruthless, coherent, simple. Since it is moreover popular it represents not only ideology but also a visible market orientation as well: something like half of voters favoured the moratorium on Muslim migration (Wong, 2016).

Moreover a key paradigm of orthodox marketing theory has been fundamental to Trump and his success. In general marketing conceives the disaggregating of some total group so that appeals can be refined (segmentation), and Trump's implicit strategy was to segment by social class and (to a degree) gender: Trump was always dominant among blue-collar males.

The policies are market -oriented in another sense as well, that is to say the alleged crises they respond to are perceived as real by many voters. Indeed, and crucially amidst the bellicose posturing, and manufacture of fantastic hallucinations, there is a sliver of truth. Crime in the great American cities is bad. There were many failures in the Obama Administration. Jobs have been exported in large quantities. Illegal immigration into the United States is massive and carries with it social costs as well as benefits. And it is also objectively the case that the material substance of the American idea is now elusive for many Americans. The Trump phenomenon arises against the background of such factors as: the decline in the certainty of employment, the flattening of worker incomes over several decades, the increasing insecurity of the middle class. 
Thus the emotions rhetorically aroused include Fear itself, which is an emotion mobilized more generally even in consumer marketing (for example in the sale of insurance). The arousal of fear and provision of a branded antidote go together and certainly have historically in the advertising industry, that is the appeal to fear is never left rhetorically un-answered and conjoined to it is the 'solution', in political terms that is to say a vote for me. Fear is selective, but it is in general very much the default strategy of political marketing. Most researchers now agree that there is a positive linear relationship between the intensity of the fear appeal and its persuasiveness (Latour and Rotfeld, 1997). Trump's rhetoric exploited fear in its evocation of an American dystopia: "And he has depicted American cities as centres of carnage, turned monstrous cops like Joe Arpaio into celebrities, told the very opposite of the truth - 'the murder rate in our country is the highest its been in 47 years" (Andersen, 2017).

More generally there is the overall question of social and political climate - the rise of a stifling political correctness and virtue signaling and public sanctimony, at least as perceived by American conservatives, and the salience of what they would regard as arcane debates. These were things which the Trump campaign exploited as political market appeals. One cannot in other words entirely dismiss Trump's efforts as alien to the domain of marketing: the product 'Trump' for example had one of the most famous slogans of all time, simple, resonant: Make America Great Again. All of this ultimately represents an effective marketing message, expressed specifically as a general entreaty to turn back the clock. Moreover with Trump nothing is quite as it might seem and it is easy to forget that he is even capable of the sly calculation of the ingratiating politician - for example he modified his line on repatriation in the late August of 2016 as he sought support from mainstream Republicans, and he has been quite prepared to drop unpopular policies. 
Further, a review of the complex relationship of political marketing to the Donald Trump phenomenon cannot ignore the role of self -branding. He was one of the best- known public figures, and brands, in the United States long before he sought the Presidency. So this is marketing in another and pre-existent sense -- he was already an entertainment brand and forged this into a political brand. Much of his political success is only explicable via the scale of his fame on The Apprentice, which was a significant media event and an act sustained over many years, and yet largely occurred beneath the radar screen of highly educated Americans. So the Trump election and presidency dissolves the boundary between politics and entertainment (as did Reagan in an earlier era): "As a business hustler and entertainer, then as candidate and president, he pedals over the top make-believe from his branded cologne and 'university' and Ceausescuesque residencies to his WWF appearances and The Apprentice to tales about millions of illegal 2016 voters and his predecessor's birth place" (Andersen, 2017).

What we have really is an actor: the Trump brand doesn't ask for belief. His preposterous bellowing and outrageous assertions creep under cognitive defences with propositions apparently too ridiculous to be taken seriously: as Austin (1962) points out, the question of truth or falsehood is irrelevant to performatives or performance utterances because they are dramaturgic ones. Missing however in the conventional anathema on Trump is recognition of the essentiality of the self- parodic element to his act. Not for nothing did he leap into a WWE wrestling bout with Vince McMahon (2007). He is in other words an entertainer, a pantomime villain even. Accusing him of fakery, of misinformation, does not really capture the essence of his political act, which is a comical turn that winks at his knowing audience, and recognises at some level their participation in this fraud by voluntarily offering him the surrender of their disbelief, their indulgence of his pantomime persona which paradoxically assigns them power because they 
accept him. This is therefore fundamentally different from other politicians who might engage in deceit and misinformation: for Trump's entire act is based on the audience knowing that what he is offering is a surreal encounter, a message via a hyper-hystericised view of political reality whose un-truths are a pre-ordained fact.

Another conceptualization of Trump and his campaigns is that he is recidivist, and belongs to an essentially pre-marketing era: not least because the core of his career was of course selling and his act expresses the theatre of selling such as the fake surprise, the waspish, verbose denigration of rival products, the theatrical elements of the performance and the constant and egotistical demanding for attention. Under J. Lees- Marshment's (2001) conception of product, sales and marketing oriented parties, he would be relegated to the first two categories. He fits in the "sales" as well as the "product" era traditionally posited as earlier historic stages in the evolution of marketing theory and practice. Sales -oriented political marketing management suited a nascent era of political marketing where the focus was on the transmission of the ideology rather than the discovery of wants, and features communication activities 'specifically deployed in a pushmarketing setting for election campaigns' (Scammell et al., 2009). This is after all conviction politics, and although many lamented their apparent demise they seem to have had a resurrection in such characters as Elizabeth Warren, Bernie Sanders and Jeremy Corbyn. The approaches pursued under such an orientation tend to be tactical rather than strategic.

\section{A Critique of Political Marketing Theory: Trump and a New Media Environment}

Trump emerges in an entirely new kind of media environment characterized by the demise of the mainstream press, of national audiences for national television channels and their substitution by free media, partisan media like Fox News and the rise of the public/ private echo chamber of 
social media. Civic discourse has become highly fragmented and its function seems not so much to inform, or open minds. as reinforce existing positions. This has become the defining feature of our time.

Yet marketing and political marketing have hardly yet theorized this, even when nearly twothirds of American adults now get some of their news from social media (and 15\% often) (Pew Research Centre, cited in Anon., 2016). Donald Trump is the candidate of a new era where rhetoric and propaganda call out the base via the arousal of fear: the new channels of persuasion have artificially magnified division leading to a classic polarization effect of which Trump was the beneficiary. Political opinion, indeterminate and even fluid, is forcibly polarized around the demagogue either antagonistic to him or exuberantly pro- him. His ascent to power is the terminus of a trend and the consequence of an atmosphere. American politics had been rancorous; it was now toxic. The self-appointed guardians of the Republic - Fox News, Sarah Palin, Anne Coulter, the T-Party - explicitly rejected consensus and pursued ideological purity with a sectarian bile that would have perplexed an earlier Republican generation (see Drutman, 2017). While news has always to some extent be segmented by channel - one thinks of the demographics of particular newspapers for example - the rise of cable and satellite in the later $20^{\text {th }}$ century enabled a much sharper focus on market segmentation. Increasingly therefore people were addressed in their own voice and in the language of their own prejudices. But social media has taken this to a whole new level (Pringle, 2016). Via social media we reinforce existing perspectives because we exclude contrary views, since its algorithms track users' likes and offer similar content.

The Trump phenomenon therefore is the symptom and end -product of radically deepening political divisions; and the bigger question is whether such polarization in society can ever again 
be papered over by conventional political marketing and orthodox campaigning. Ethnonationalist rhetoricians - if that is what we call them- are a response to the conditions of modernity and a particular set of conjoined pressures that have merged together in historic time.

\section{A Critique of Political Marketing Theory: Trump, Followership and the 'Knowability' of the Target}

The essence of marketing is customer orientation, which means of course that we must conceive its targets as customers rather than some other descriptor: this author has argued that "political marketing like consumer marketing rests on some notion of 'consumer' sovereignty, that value is derived from the them, and this conceptualisation is different from competitor notions of people as citizens, as in political science, or Marxist ones of the suppressed proletariat" (O’Shaughnessy, 2017).

Essentially then the fallacy underlying consumer marketing and by extension political marketing is that of the knowability of the consumer. The premise is that consumers have a clear set of defined desires as arranged in a hierarchical sequence of preferences and involving trade-offs, and similarly with voters since they are also consumers (Bartle and Griffiths, 2002). Marketing theory errs in over-rationalising consumption.

Such a perspective betrays its ancestry in the rational choice theory inherent in micro- economic models, so that even applied to consumer marketing it represents a crude simplification. Applied to politics it neglects the key role of persuasion or the question of feasibility, or indeed the fact that voters often have multiple and indeed contradictory objectives. 
The knowability of the public mind is thus an assumption of political marketing theory and a precondition for political marketing practice. But people want irreconcilable things, or they are confused and ambivalent about satisfying choices, not least because they lack the information necessary to make an informed decision. So there is ambiguity - such that the function of political communication is both leadership and followership: British Prime Minister (1922-23) Andrew Bonar Law once said "I must follow them, I am the leader" (Parris, 2016), and as a caricature of political marketing this might suffice. But only the naive theoretician would subscribe to it: there has to be 'leadership' as well as 'followership' because the role of a leader is to illuminate certain possibilities, trajectories and opportunities of which target groups may be unaware. And data has to be interpreted and is rarely self -explanatory: a so-called leader who slavishly followed the desires of the key markets segments as determined via polling, ie market intelligence, might not succeed.

Thus in its diminution of the notion of leadership political marketing theory makes normative not leadership but 'followership', where the 'leader' is simply a measurer and a collater and nothing more. But Trump is not simply reflecting his audience and acting as the incarnation of its political beliefs. He is actually shaping those beliefs and giving ideas of possibility which the audience had not necessarily had before. He is moreover saying things that many people believed but would not have dared to express because of the social impropriety. He articulates the unsayable and legitimates the unmentionable. (O'Shaughnessy, 2002) Moreover the supposition behind the economist's concept of rational choice theory as applied to political science (or such models as the multi-attribute model in consumer behavior, Hayer at el, 2013), is that political consumers do indeed act rationally, but all the evidence is that they act emotionally, they do not weight and evaluate the various alternatives and trade-offs. 
Political marketing is not commercial, but public-cum-political (Lock and Harris, 1996), a vivid public theatre acted and refracted through multiple media. This represents a more turbulent environment than is the case in consumption and product- market situations - the fluidity and unpredictability of a campaign, the role of press in filtering and predetermining political phenomena as well as, more recently, the rise of social media-enabled fake news. Nor is the speed of contemporary political processes an evolution captured in either the theory or the concept of political marketing: a 24-hour news cycle, numerous news channels and forms such as Facebook have for example put a new premium on the Blairite imperative of rapid rebuttal. Political rhetoric today has become a Tweet-enabled rhetoric of refutation.

\section{A Critique of Political Marketing Theory: Theoretical Backwardness}

Another major reservation is that political marketing theory is essentially static, backward even, that the extant theory remains encumbered by an earlier phase of consumer marketing theory, and this is illustrated by the dominance of operational and marketing mix derived notions in the political marketing literature (Lloyd, 2003). Political marketing scholars have un -critically adopted, not adapted, the core principles of the 'mother' discipline. The limitations of political marketing theory are significant because they are characterized as transactions with an implicit or explicit notion of an active "seller" and passive target who are joined together in pursuit of utility- maximizing goals, and thus inherits the reductivist and simplificatory marketing textbook nostrums (Gummesson, 2002). For example one obvious limitation is the consequent focus on political engagement as merely an exchange function, a series of isolated transactions with no ulterior meaning. The Trump phenomenon however is identity- driven and existential, and neither evoked nor explained by conceptual structures derived from consumption or the language 
of exchange relationships: as Goebbels said, no man ever died for the eight hour day

(O’Shaughnessy, 2016).

\section{Deviating From the Script: Trump’s Repudiation of Marketing Orthodoxy}

What was most noteworthy about Trump's campaign was its rejection, until late in the day, of the orthodox techniques of political marketing which have served other political candidates for decades: political advertising, direct mail, posters and so forth. Trump in contrast relied on oratory and dramaturgy before a live audience relayed via television. Clearly Trump's success can also be represented as a reaction against normative political marketing, the packaged, groomed candidate uttering cautious, ambivalent words and sitting permanently on the fence, reluctant to use visceral language to excoriate phenomena which many voters find repulsive, and so forth. A John Kerry or a Mitt Romney might be characterized thus. In other words the calculating political careerist, constantly measuring opinion and constantly running with it, never articulating a perspective independent of what the polls are telling him or her, refusing to show leadership, - indeed how many of democracy's leading politicians does such imagery evoke? Voters became so tired of merchandised insincerity that they welcomed a 'punk' into their midst?

But in key ways Trump repudiates entirely any political marketing script that ever existed, indulging eccentricities that no strategist or tactician would advocate, no other President would ever affect. This is Trump the fantasist, the un-marketer, the strange, mad, maddening tribune of the people, yet perversely managing to turn delusions to political advantage. But then Trump has long been aware of the value of the irrationalizing appeal to fantasy, writing in The Art of the Deal (1987): “The final key to the way I promote is bravado. I play to people's fantasies". He 
argued that "People may not always think big themselves, but they can still get very excited by those who do. That's why a little hyperbole never hurts. People want to believe that something is the biggest and the greatest and the most spectacular". And then again "I call it truthful hyperbole. It's an innocent form of exaggeration - and a very effective form of promotion" (Trump, 1987). Trump's public fictions are a deeper form of truth to the truly committed and a form of self- deception rather than other -deception (which is lying). But they are still fictions: 'If more than $16 \%$ of Americans could locate Ukraine on a map, it would have been a really big deal when Trump said that Russia was not going to invade - two years after they had invaded it' (Tim Egan, 2016).

Successful polemicists however never commit the mistake of asking for belief. Where persuasion is 'manipulative', we envisage a passive recipient, a kind of hypodermic stimulus -response model; but that is hardly a realistic descriptor of what actually occurs. The target is willing, proactive even. Part of the reason for their credulity is so-called confirmation bias (Nickerson, 1998) - the bias towards discounting information that contradicts one's thinking and sticking to assumptions, despite evidence to the contrary. It is only when we remember Trump is really offering an amalgam of truth and fiction, and that the fiction enhances the truth, that we begin to understand the core of his vainglorious act and why it works. Some might see this as the "false consciousness' of Marxist ideology.

Grievances are imaginary as well as real. Thus "If I'm elected we're all going to be saying Merry Christmas again" is vintage Trump oratory, but who is actually trying to ban this? Then there are the fictitious events which did not actually happen, everything from the 'Bowling Green massacre' to the 'terrorist attack' in Sweden. Trump merely invents. But "Mexico must pay for the wall" or "The concept of global warming was created by and for the Chinese in order to 
make us manufacturing non-competitive" (Fields, 2017) are a co-creation of speaker and audience. The lies of the populist then are something more than lies, for the populist the untruths represent a deeper form of truth: in other words the reality we manufacture doesn't have an objective or tangible essence. This is not of course to suggest that Trump knowingly told a lie, rather that the idea of truth has no value for him, a proposition is sufficiently 'true' if it feels true and fits an ideological schemata.

Then there is his rhetorical turn, a compulsive stream of consciousness without precedent in political practice or foundation in marketing theory. It is quite simply Trump, and the manner in which his outlandish persona is rhetoricised incessantly and publicly for much of the night and day deviates completely from the political marketing script. Thus his verbal incontinence, manifest in his continuous tweets, constitutes a kind of running commentary on his presidency, assaulting imaginary foes and those who have offended him. Trump has a talent for outraging public opinion while simultaneously manipulating it. He re-tweeted deceitful anti-Muslim memes from Britain First and rebuked Theresa May when she protested. As for the press, it was now an 'enemy of the people' (Rutenberg, 2017). After the Charlottesville riots he accused people he called the "Alt. left' of "swinging clubs" as they "came charging at, as you say, the Alt. right" (Shear and Hebberman, 2017). Then there were those 'shithole countries' and the boast that he had a bigger nuclear button than Kim Jong-un. All this does no harm with his base, which has remained consistent at around $30 \%$ of voters despite the deliberate derision of convention. It is, almost, a kind of de-marketing or anti-marketing.

The study of Trump and his phenomena invoke methods both ancient and modern - that is to say he is a rhetorician, but relies heavily on one very particular form of social media, that is to say Twitter. The conventional rhetoric of politics with its glib phrases, slogans, sound-bites, is 
recognizably kindred to the rhetoric of consumer marketing. But what Trump offers is a particularized sub-species of political rhetoric, one lacking the calculation of conventional language. Again therefore the inference is that we completely re-write- or discard- the political marketing script. This means that in the analysis of political marketing we must bring into play other concepts such as populism and propaganda and rhetoric, terms which appeared to have been consigned to an earlier period in history but which we must now redeploy. As the tub thumping parish demagogue of cyberspace, Trump resembles no previous resident of his high office. But polemical rhetoric defines him, rhetoric without calculation, without strategy. Some critics are even reminded of someone else: one Oxford researcher, Dr. Kevin Dutton, has even claimed that Donald Trump exhibits 'more psychopathic' traits than Hitler (Williams, 2016).

\section{Conclusions}

So is political marketing defunct, designed for the kind of centrist politics which no longer exist in our newly polarized order? The case is by no means entirely proven; politics was often malicious in the past and maybe we should have raised questions before about whether the political marketing model was ever appropriate. American elections were never a parlour game. Examples from the past are the infamous 'Daisy' advertisement of 1964 (Mann, 2011) where a little girl counting flower petals morphs into a nuclear explosion, implying that Goldwater would have an itchy finger on the nuclear trigger, or the charlatanry of the 'Swift Boat Veterans For Truth' on George W. Bush's behalf in 2005.

But Trump makes norm violation not an occasional recourse but the governing feature of his campaigning and conduct of office. Is what Trump offers merely unconventional political 
marketing, or a different genre: can it still sustain that descriptor? But political marketing, it has to be said, has regularly been guilty of norm violation, of offending civic decency: half a century of negative advertising as the default position in American campaigning gave us such treasures as 'Willie Horton' (1988), a pro- George H. Bush campaign advertisement showcasing the release on furlough of a black murderer-rapist (McIlwain and Caliendo, 2011).

Much in fact is governed by whether we regard the Donald Trump phenomenon as one- of-akind, sui generis, or the harbinger of a new form of political discourse which others will emulate. The question also has a broader relevance beyond the USA - the emergence of populists like Duterte in the Philippines for example or Victor Orban in Hungary or Erdoğan or even Putin himself raises the issue of whether Trump is part of a (recidivist) trend throughout the world. Has Trump changed the practice of politics for ever? For example the parallel left-wing stars - Bernie Sanders and Jeremy Corbyn - suggest the future study of political communication may be dominated by concepts from rhetoric rather than political marketing, that is to say the earlier and indeed ancient conceptualization could replace the modern and contemporary one. Will the rest of the world, or some of it, emulate the ethno-nationalist rhetorical strategy that so characterises Trump?

The Trump campaign and Presidency does then re-write the script. But the question left unanswered is whether it is a specific time- limited charisma- driven phenomenon, and an evanescent one (and also a paradox since it is a species of anti-marketing that is a form of marketing). The further unresolved issue is conceptual: whether this is an extra- marketing realm or merely an extension of marketing; is the difference such as to stretch the marketing concept beyond its conceptual boundaries, so that we are in fact dealing with a different phenomenon? 
Are we in other words just writing about an evolutionary form of political marketing, or a different construct better accessed by terms like polemic and propaganda?

\section{References}

Anon. (2016). Yes, I'd lie to you. The Economist, September 10, 17- 20.

Andersen, K. (2017). Hands up. It's showtime. New York Times, September 8.

Austin, J.L (1962). How To Do Things With Words. London: Oxford University Press.

Baines, P., O’Cass, A., Ormrod, R., \& O’Shaughnessy, N.J (2012). Political Marketing Orientation: Confusions, Complications, Criticisms. Journal of Political Marketing, 11(4),

Bartle, J. and Griffiths, D. (2001). Social-psychological, economic and marketing models of voter behaviour compared. In O'Shaughnessy, N.J. and Henneberg, S. (Eds.), The Idea of Political Marketing, Connecticut: Praeger.

Dermody, J.; Scullion, R. (2003). Exploring the Consequences of Negative Advertising in Liberal Democracy. Journal of Political Marketing, 2(1), 77-100.

Drutman, L. (2017). Yes, the Republican Party has become pathological. But why? Vox, September 22.

Egan, T. (2016). The dumbed down democracy. New York Times, August 27.

Fields, Z. (Ed.)(2017). Collective Creativity For Responsible And Sustainable Business Practice. Hershey, PA : IGI Global.

Gummesson E. (2002). Practical Value of Adequate Marketing Management Theory. European Journal of Marketing, 36(3), 325-349.

Hayer, W., MacInnis, D. and Pieters, R. (2013), Consumer Bahavior, Sixth edition. Mason, Ohio: South Western/ Cengage Learning.

Henneberg, S. C. (2002). Understanding Political Marketing. In N. J. O’Shaughnessy and S. C. Henneberg (eds.) The Idea of Political Marketing. Westport: Praeger, pp. 93-170.

Henneberg, S.C, O'Shaughnessy, N.J (2007). The Selling of The President 2004: A Marketing Perspective. Journal of Public Affairs, 7(3).

Henneberg, S.C, O’Shaughnessy, N.J (2009), 'Political Relationship Marketing: Some MicroMacro Thoughts'. Journal of Marketing Management 25(1/2), 5-29. 
McIlwain, C., and Caliendo, S. (2011). Race Appeal: How Candidates Invoke Race In US Political Campaigns. Philadelphia: Temple University Press,

Johnson, D. (2001). No Place for Amateurs: How Political Consultants Are Re-shaping American Democracy. New York: Routledge.

Latour, M, and Rotfeld, H. (1997). There are threats and (maybe) fear-caused arousal: theory and confusions of appeals to fear and fear arousal itself. Journal of Advertising, 26(3), 45-59.

Lees-Marshment, J. (2001). The Product, Sales and Market-Oriented Party: How Labour Learnt to Market the Product, Not Just the Presentation. European Journal of Marketing, 35 (9/10), 1074-84.

Lloyd, J. (2003). Square Peg, Round Hole?: Can Marketing-Based Concepts such as 'Product' and the 'Marketing Mix' Have a Useful Role in the Political Arena? Paper presented at the Political Studies Association Conference, 2003, April 15-17, University of Leicester.

Lock and Harris (1996). Political Marketing - Vive la Différence. European Journal of Marketing, 30(10), 14-24.

Mann, R. (2011). Daisy Petals And Mushroom Clouds; LBJ, Barry Goldwater And The Ad That Changed American Politics. Baton Rouge: LSU Press.

Morris, D. (1997). Behind The Oval Office. New York: Random House.

Nickerson R. (1998). Confirmation bias: a ubiquitous phenomenon in many guises. Review of General Psychology, 2(2), 175-220.

O’Shaughnessy, J. and O'Shaughnessy, N.J. (2002). The Marketing Power of Emotion. Oxford: Oxford University Press.

O’Shaughnessy, N.J (2016). Selling Hitler: Propaganda And The Nazi Brand. London: Hurst.

O’Shaughnessy, N.J (2017), Marketing The Third Reich: Persuasion, Packaging and Propaganda. London: Routledge.

Parris, M. (2016). Scorn: The Wittiest And The Wickedest Insults In Human History. London: Profile Books London.

Pringle, R., (2016). Social media is blinding us to other points of view. CBC News, November 14.

Rutenberg, J. (2017). Target practice: Trump's latest attack on journalism has a particularly ugly edge. New York Times, August 24.

Trump, D. (1987). The Art of the Deal. New York: Random House.

Scammell, M., Henneberg, S. and O’Shaughnessy, N.J (2009). Political Marketing Management and Theories of Democracy. Marketing Theory, 9 (2), 165-188. 
Shear, M. and Hebberman, M., (2017). Trump defends initial remarks on Charlottesville; Again blames both sides. New York Times, August 15.

Shear, M. and Hebberman, M., (2017). Volume rising in nativist talk from President. New York Times, August 18.

Sheth, J., Gardner, D., and Garrett, D. (1988). Marketing Theory: Evolution and Evaluation. New York: Wiley.

Williams, Z., (2016). Is Trump a psychopath? I'd call him a narcissist. The Guardian, August 23.

Wong, Kristina, (2016). Half of American voters back Trump's Muslim ban. The Hill, March 29.

\section{Playing with Marketing rhetoric}

Barbara J. Phillips 
When my older sister's house burned down, the first things she replaced were her six Lego Creator buildings. Her possessions suddenly were reduced to the clothes on her back and the random items in her purse, yet she spent every evening painstakingly reassembling the 2,500 pieces of Lego that comprised each building of the Lego restaurant, bank, and cinema she had lost. That same summer, my younger sister got up at 6:00 a.m. on a Saturday morning and spent five hours walking around her neighborhood's community garage sale. She came home with a children's plastic Hello Kitty bracelet and a sunburn, yet she described it as the "best day ever!" And I have to admit, that summer I binge-watched Riverdale, a live-action TV melodrama targeting an audience half my age following the exploits of the comic book characters Archie, Jughead, Betty, and Veronica.

What these stories all have in common is that they illustrate the importance of play in the lives of adults. The dictionary definition of play is: the basic human activity of employing oneself in diversion or recreation; to amuse oneself; to do something that is not to be taken seriously. For children, play has been studied extensively and is correlated with happiness and effective functioning (Eberle, 2014; Singer, 2009). However, play for adults has been viewed as culturally suspect, "as no more than retained childishness, a distraction from both productive work and 'useful' consumption”' (Molesworth \& Watkins, 2016, p. 515). Only a few scholars are beginning to understand that adult play can lead to positive and important consequences (Johnson, 2016).

Play is theoretically difficult to define (Eberle, 2014), for it encompasses everything from spear fishing to Sudoku — or as mentioned, brick-building to garage-saling to binge-watching. A key element of play is pleasure, which functions as "the keystone or hub of play, both as a defining trait and an incentive to play some more" (Eberle, 2014, p. 223). This paper asserts that it is time 
marketers took the concept of play seriously. Almost forty years ago, Holbrook and Hirschman (1981, p. 135) wrote a seminal article stating a consumer "seeks fun, amusement, fantasy, arousal, sensory stimulation, and enjoyment" - calling this the pleasure principle. The consequences of consumption are not just functional benefits and utilitarian value but the fun and pleasure consumers can derive. As a result of that article, marketing researchers resolved to understand the pleasure principle better. Three decades later, a review of hedonic consumption (Alba \& Williams, 2012, p. 3) finds marketers' ideas of pleasure have been narrowly framed as product purchase enjoyment and ultimately, "consumer research has largely failed to capture it." Further, marketing researchers often have overlooked what it is that truly brings consumers pleasure, which may not be a product at all.

\section{Play and Pleasure in Advertising Rhetoric}

Campbell (1987) asserts that pleasure is not an intrinsic property of a product, but is a reaction that individuals have when encountering any product-related stimuli, such as an ad. "The essential activity of consumption is thus not the actual selection, purchase or use of products, but the imaginative pleasure-seeking to which the product image lends itself' (p. 89). Other scholars have called this consumption of the mind (d'Astous \& Deschenes, 2005) and it is a key component of advertising rhetoric. Before rhetorical figures were even named-when they were still referred to as 'resonance' or 'wordplay' - the defining characteristic of advertising rhetoric was that it evoked the pleasures of the text in consumers' minds (McQuarrie \& Mick, 1992). Consumers' experiences of pleasure are elicited by encountering a specific type of ad stimuli providing ambiguity or incongruity that has to be successfully decoded to understand the meaning of the text. "The reward comes from processing a clever arrangement of signs" (McQuarrie \& Mick, 1996, p. 427). 
After rhetorical figures were defined in the marketing literature as "an artful deviation, relative to audience expectation, that conforms to a template independent of the specifics of the occasion where it occurs" (McQuarrie \& Mick, 1999, p. 38), artful deviation was identified as both the source of the pleasure in the ad and the motivation for processing it. "Texts that allow multiple readings or interpretations are inherently pleasurable to readers... the initial ambiguity is stimulating, and the subsequent resolution rewarding” (McQuarrie \& Mick, 1999, p. 40). Both the enjoyable language and the act of resolving ambiguity in rhetorical works has been thought to provide pleasure to individuals since the time of Aristotle (Huhmann \& Albinsson, 2012). Therefore, play lies at the core of advertising rhetoric and with play, the pleasures associated with playing with rhetoric.

Unfortunately, rhetorical pleasure has been narrowly defined by marketing researchers, reducing it to attitude toward the ad (Aad) and attitude toward the brand (Abr). Other cognitive measures, such as comprehension, complexity, memorability, and involvement have taken center stage in rhetorical research; play has disappeared, and pleasure has been reduced to scaled measures of liking. However, recent research suggests that liking —as measured by the common attitude toward the ad scales - cannot capture the essence of consumers' positive responses to advertising rhetoric (Huhmann \& Albinsson, 2012). Thus, it is time for marketing scholars to move play and pleasure back into the forefront when exploring marketing rhetoric.

A way forward might be to start thinking of consumer processing of rhetorical figures as combinatory play. Combinatory play uses both conscious and unconscious mental processes to perceive patterns, links, and associations between two or more related ideas. "In all cases of combinatory play, the creative process involves the discovery of hidden similarities between two or more things or ideas making their connections and relationships clear" (Stevens, 2014, p. 
101). This depiction is just like the processing described by marketing researchers to explain how consumers solve the puzzle inherent in advertising rhetoric (McQuarrie \& Mick, 1999). It is important to label this process 'combinatory play,' because it emphasizes the lost ideas of play and pleasure in the cognitive exercise of making advertising meaning. In addition, it focuses research attention on an overlooked aspect of marketing rhetoric: imagination.

Play is "imagination in action" (John-Steiner, Connery \& Marjanovic-Shane, 2010, p. 11) and understanding imagination is necessary to understanding play (Stevens, 2014). Lev Vygotsky, a ground-breaking Russian psychologist who studied imagination, creativity, and play, defined imagination as a complex form of mental activity where consciousness departs from reality (1987). Marketing scholars can look to Vygotsky's 'laws' of imagination (2004) to provide four areas for novel research on advertising rhetoric: (a) personal experience, (b) shared play, (c) curiosity, and (d) imaginative reality.

Vygotsky's first tenet of imagination is that everything a person creates in imagination is based on elements taken from previous experience. "The creative activity of the imagination depends directly on the richness and variety of a person's previous experience because this experience provides the material from which the products of fantasy are conducted" (Vygotsky, 2004, p. 14). This importance of experience explains why imagination actually is richer and more developed in adults than in children (Vygotsky, 2004). Marketing research affirms that consumers use their previous experience with advertising, product categories, and cultural knowledge to understand advertising rhetoric (Phillips, 1997). However, this same study uncovered a core group of consumers who use their experience to comprehend the rhetorical message, but don't derive pleasure from this process (Phillips, 1997). These literalists disliked the imaginative play needed to engage rhetorical ads and felt it was not necessary. 
Marketing researchers have not yet examined this group of consumers to see why they do not want to use their imaginations. Singer (2009) notes that children who are encouraged in makebelieve play score higher on the personality trait of openness later in life and are better at solving problems. Is there some personality trait or life experience that discourages the use of imagination? Perhaps these literalists have internalized cultural norms prohibiting adults from playing (Molesworth \& Watkins, 2016). A fruitful area of study would be to segment consumers based on their approach to (or avoidance of) the play and pleasure offered by advertising rhetoric, much as Garcia (2013) has sorted jigsaw puzzle players into four distinct motivational and procedural groups. This typology of consumer response would deepen understanding of the theoretical and managerial implications of using rhetoric in advertising beyond current conceptualizations.

Vygotsky's second tenet states that imagination is shared play because through imagination, an individual can take on the experiences of another person and broaden his or her understanding of an issue. "He is not limited to the narrow circle and narrow boundaries of his own experience but can venture far beyond these boundaries, assimilating, with the help of his imagination someone else's historical or social experience" (Vygotsky, 2004, p. 17). In this way, the consumer and marketer co-create the meaning of the advertisement, with the consumer sharing the marketer's imagination and point of view. Playing together, in this manner, can strengthen the relationship between the participants and increase the bond they feel towards one another (Eberle, 2010; Marjanovic-Shane, 2010). This outcome-increasingly strong ties to the brand, the advertiser, and the company because of shared play — has not been explored yet in the context of advertising rhetoric. 
Vygotsky's (2004) third tenet is that emotions color our imagination in terms of the impressions, thoughts or images we select and associate. One of the key emotions associated with imagination is curiosity, a "disposition to inquire, investigate, or seek after knowledge; a desire to gratify the mind with new information or objects of interest; inquisitiveness" (Kashdan, Rose \& Fincham, 2004, p. 291). Individuals voluntarily seek out situations they know will induce curiosity, such as reading mystery novels and completing crossword puzzles, and curiosity exerts a powerful motivating force because of humans' innate drive to make sense of the world (Loewenstein, 1994). Marketers can harness the power of curiosity to ensure that consumers engage with their rhetorical advertising by providing some information, leaving out other information, and drawing attention to this lack of knowledge. "The proposed theory views curiosity as occurring when an individual's informational reference point becomes elevated in a certain domain, drawing attention to the information gap" (Loewenstein, 1994, p. 93). Loewenstein suggests five different ways to increase curiosity and stir consumers' imaginations that future research can examine in a marketing rhetoric context. In addition, marketers can measure consumers' innate curiosity with the Curiosity and Exploration Inventory (Kashdan, Rose \& Fincham 2004); these authors suggest curiosity is long overdue for attention in applied research.

Vygotsky's (2004) fourth tenet of imagination is simply that imagination ultimately becomes reality, because we act on our imaginations in the real world. The ideas that are conjured up in our minds become just as real as our memories and influence our attitudes and our behaviors. "In play, people envision and enact the possibilities of living in their societies; and for that reason, play is an important agency of social and cultural change" (Henricks, 2014, p. 294). This tenet underscores the importance of imagination as a construct to be added to marketing scholars investigations of advertising rhetoric and its influence on consumer persuasion. 
This article has attempted to demonstrate that play and pleasure are not just a side-note or a byproduct of marketing rhetoric, but the core and key to its understanding. By embracing advertising rhetoric as combinatory play founded on the pleasure principle, marketing scholars can begin to explore the role of imagination, experience, shared play, and curiosity in the lives of consumers. These concepts have real-world consequences for marketers. Such an exploration will re-invigorate the study of advertising rhetoric and open the eyes of its scholars to new insights. As Brown (2001, p. 116) prophesied, "surely, if the postmodern revolution of recent years has taught us anything, it is that rationality is not the be all and end of all intellectual endeavor. Intuition, inspiration, and imagination are just as important as analysis, planning, and control, possibly more so."

\section{References}

Alba, J. \& Williams, E. F. (2012). Pleasure principles: A review of research on hedonic consumption. Journal of Consumer Psychology, 23(1), 2-18.

Brown, S. (2001). Marketing: The retro revolution. London, UK: Sage Publications.

Campbell, C. (1987). The romantic ethic and the spirit of modern consumerism. Oxford, UK: Basil Blackwell.

d'Astous, A. \& Deschenes, J. (2005). Consuming in one's mind: An exploration. Psychology \& Marketing, 22(1), 1-30.

Eberle, S. G. (2014). The elements of play: Toward a philosophy and a definition of play. American Journal of Play, 6(2), 214-33.

Garcia, A. C. (2013) Explorers, detectives, matchmakers, and lion tamers: Understanding jigsaw puzzlers' techniques and motivations. American Journal of Play, 5(3), 308-32.

Henricks, T. S. (2014). Play as self-realization: Toward a general theory of play. American Journal of Play, 6(2), 190-213.

Holbrook, M. B. \& Hirschman, E. C. (1982) The experiential aspects of consumption: consumer fantasies, feelings, and fun. Journal of Consumer Research, 9(September), 132-140. 
Huhmann, B. A. \& Albinsson, P. A. (2012). Does rhetoric impact advertising effectiveness with liking controlled? European Journal of Marketing, 46(11), 1476-1500.

Johnson, S. (2016). Wonderland: How play made the modern world. New York, NY: Riverhead Books.

John-Steiner, V., Connery, M. C. \& Marjanovic-Shane, A. (2010). Dancing with the muses. In M. C. Connery, V. P. John-Steiner \& A. Marjanovic-Shane (Ed.), Vygotsky and creativity: Cultural-historical approach to play, meaning-making, and the arts (pp. 3-15). New York, NY: Peter Lang.

Kashdan, T. B., Rose, P. \& Fincham, F. D. (2004). Curiosity and exploration: Facilitating positive subjective experiences and personal growth opportunities. Journal of Personality Assessment, 82(3), 291-305.

Loewenstein, G. (1994). The psychology of curiosity: A review and reinterpretation. Psychological Bulletin, 116(1), 75-98.

Marjanovic-Shane, A. (2010). From yes and no to me and you: A playful change in relationships and meanings. In M. C. Connery, V. P. John-Steiner \& A. Marjanovic-Shane (Ed.), Vygotsky and creativity: Cultural-historical approach to play, meaning-making, and the arts (pp. 41-59). New York, NY: Peter Lang.

McQuarrie, E. F. \& Mick, D. G. (1992). On resonance: A critical pluralistic inquiry into advertising rhetoric. Journal of Consumer Research, 19(September), 180-197.

McQuarrie, E. F. \& Mick, D. G. (1996). Figures of rhetoric in advertising language. Journal of Consumer Research, 22(March), 424-438.

McQuarrie, E. F. \& Mick, D. G. (1999). Visual rhetoric in advertising: Text-interpretive, experimental, and reader-response analysis. Journal of Consumer Research, 26(June), $37-54$.

Molesworth, M. \& Watkins, R. D. (2016). Adult videogame consumption as individualised, episodic progress. Journal of Consumer Culture, 16(2), 510-530.

Phillips, B. J. (1997). Thinking into it: Consumer interpretation of complex advertising images. Journal of Advertising, 26(2), 77-87.

Singer, J. (2009). Researching imaginative play and adult consciousness: Implications for daily and literary creativity. Psychology of Aesthetics, Creativity, and the Arts, 3(4), 190-9.

Stevens, V. (2014). To think without thinking: The implications of combinatory play and the creative process of neuroaesthetics. American Journal of Play, 7(1), 99-119.

Vygotsky, L. S. (1987). The collected works of L. S. Vygotsky, Volume 1: Problems of general psychology. R. W. Rieber \& A. S. Carton (Ed.). N. Minick (Trans.). New York, NY: Plenum Press. 
Vygotsky, L. S. (2004). Imagination and creativity in childhood. Journal of Russian and East European Psychology, 42(1), 7-97.

Marketing: Rhetoric and Reality

\author{
David Tonks
}


We shall not cease from exploration

And the end of all our exploring

Will be to arrive where we started

And know the place for the first time.

T. S. Eliot,

Little Gidding, Four Quartets.

Back in 1978 and after a few years working in marketing or marketing related employment, I entered the world of the marketing academy, initially as a postgraduate student. At that time, for some years earlier and for some to come, major themes in the prevailing academic discourse included the inherent nature and the proper domain of marketing but what surprised me, as a newcomer, was the absence in the debates of any mention of persuasion. By way of example, Hunt (1976) was a major player in this particular enquiry and he articulated a structured approach to understanding the various dimensions and applications of marketing but nowhere in this magisterial and apparently comprehensive assessment was there a single mention of persuasion as a characteristic of marketing activity.

So, what is marketing? Formally, marketing was usually recognised as being a hybrid academic discipline drawing from microeconomics, sociology, psychology, statistics, operational research and elsewhere with marketing variously presented inter alia as a philosophy, an orientation, a concept, a system, a process or a function and all of these either singly or collectively constituted the 'marketing era' which had been preceded by the 'production' and the 'sales' eras. A connected and recurring discussion concerned whether marketing was an art or a science while 
the competing claims of realism and relativism created sometimes heated debate. At that time and ever since, marketing was being transported into arenas where it was previously unknown, unrecognised or only marginally represented including services and the 'non-profit' sector, higher education being but one example and associated with such hegemonic tendencies, there were frequent calls to bridge the gap between marketing theory and marketing practice although there was little that could truly be termed 'marketing theory'.

With such a hinterland, marketing was explained and defined in many ways and sometimes this was simply for the benefit of different audiences. Demarketing was recognised as being relevant in some cases. Later, there were some moves to incorporate feminist ideology into marketing. At the level of hands-on marketing management, marketing could be one or a combination of, for example, consumer, B2B, service, corporate, global, social, customer-focused, market-driven, niche, one-to-one, precision, integrated, multi-level, sustainable, ethical, and later, viral and digital. It's a long list of off-shoots. Consumer studies and organisational marketing were developing in parallel and then shifting away on their own tangents from the mainstream. The quest for distinctive identity and legitimacy was part of the zeitgeist and nowadays, some of these and related issues persist but exchanges and relationships are usually central to the more generic conceptualisations of marketing where the widely accepted view is that marketing is concerned with the activities, organisations and techniques associated with the supply of goods and services of value to customers and other stakeholders - or something along those lines.

But, here's the thing - the quiddity of marketing. Exchanges of all kinds and relationship management are undoubtedly the concern of marketing but back in the late 1970s and ever since, I have always been struck by the absence of persuasion as one of the basic 'essences' of marketing. Quite why this has been the case is something of a mystery to me. While the notion of 
persuasion exists in some approaches to communication, or the 'promotion' of the '4Ps', it is pretty much absent from probably all recognised explanations and definitions of marketing with some authors making a point of denying its relevance which to me, at least, is bizarre. As Hackley (2003) pointed out, any attempt to define marketing '...is itself ideological in character in that definitions carry silent but constitutive paradigmatic assumptions'. What is excluded from a definition may carry as much weight as what is included. From all my experiences as an actual or potential consumer, from my exposure to marketing management, from my deliberations as a marketing academic, and then from some modest consultancy work, the underlying and effectively quotidian characteristic of marketing usually included a big chunk of persuasion and particularly so in consumer markets. The idea that marketing seeks to manufacture and mould desire is and always has been popular out on the streets and, I would say, amongst marketing practitioners who are so often concerned with establishing imperfect markets characterised by brand loyalty together with inelastic demand curves and to do this, marketing beguiles, seduces and entraps. It persuades. To varying degrees and in different ways, beyond basic needs we are all gullible, susceptible to persuasion, and marketing has systematic and purposeful agency. Yet, in spite of such personal observations of marketing reality which I think are commonly held, the notion of persuasion is missing from conceptualisations of marketing, from the marketing literature and from marketing curricula. There are exceptions and maybe things are changing.

Persuasion is synonymous with rhetoric and its ancient practitioners, the Sophists. Thus began a personal odyssey with the view that this observable phenomenon of rhetoric in the modern world could provide an additional framing concept for marketing in general and marketing management in particular. Williams (2009) described how Socrates explained to Phaedrus, 'Is 
not rhetoric, taken generally, a universal art of enchanting the mind'..." which seems to be fairly central to many marketing phenomena and much of marketing in action. It was a lengthy and challenging journey because it had to begin with the Ancients and the acquisition of at least a passing familiarity with the works of, for example, Plato, Aristotle, Socrates, Isocrates, Corax, Gorgias and Cicero. I freely confess that my familiarity remains just that - passing - and the same comment applies to the work of recent and current scholars. This is a major confession given the erudition amongst academics who specialise in rhetorical studies and who may well be appalled by the encroachment and the borrowing. I also alighted with gratitude upon what was for me the apposite contribution by Laufer and Paradeise (1990) who wrote of Sophism and marketing, '...two techniques which hold identical positions with respect to action, justify themselves in the same manner and have appeared in structurally analogous conditions'. These authors had already arrived, convincingly, at the kind of position I was trying to reach. Eventually, a paper of my own saw the light of day (Tonks, 2002) and another confession would be that when it appeared, I felt some apprehension at what might be seen as a presumptuous and immodest set of claims.

However, I remain convinced that there is a great deal of potential exploration into the relevance and role of rhetoric in understanding and implementing marketing. At the level of definitions and of epistemology, perhaps marketing continues in a 'pre-paradigmatic' state, less in the strict sense that Kuhn (1962) used the expression but more in terms of the opportunity for alternative perspectives on the observed world - in this case, the world of exchanges and of relationships, both of which are at least to some degree governed by the use of rhetoric. Maybe generic definitions of marketing will eventually recognise the relevance of rhetoric. For marketing practitioners, the classic principles and devices of rhetoric remain fundamental and the potential 
for further application must be huge and not just confined to the to the nuts and bolts of efficient and effective management. As far as academic research is concerned, there certainly seems to be a gathering momentum behind the number of publications which deal with the rôle of rhetoric in marketing or with related concerns but this remains a largely uncharted territory, so far. The contributions in this special edition of the journal will give some signals for new directions.

As for pedagogy, the history here is interesting. Rhetoric used to be one element of the 'trivium' along with logic and grammar, these being the building blocks of classical education. The presence of rhetoric in education of the privileged blossomed during the Renaissance but later faded in British education and this is sometimes attributed to the effect of the Enlightenment and the diminishing authority of the spoken word during the eighteenth century. However, this period did feature the 'belles lettres' movement and also a shift towards understanding political discourse from a rhetorical stance. With the teaching of rhetoric, the emphasis was on oratory or the written word and this is how it is commonly understood today - either in that way or through something like the now corny cliché 'rhetoric and reality' coupled to almost any issue. In common usage and despite the intellectual heritage, the labels 'sophistry' or 'rhetoric' often have a derisory or abusive edge.

Now, in 2018 and forty years after my first encounters with the marketing academy, I wonder how an embryonic interest in rhetoric and marketing will mature, in the UK and elsewhere? As far as the teaching of rhetoric is concerned, the subject appears as a topic in UK secondary education and perhaps worth noting is the recent announcement that a London free school is now building its curriculum around the classical trivium, including rhetoric. In UK tertiary education, rhetoric obviously appears in philosophy and classics and it also crops up in disciplines such as English literature, communication studies, linguistics, literary criticism, politics and law but at 
the undergraduate level and although many would lay claim to it as a component, rhetoric does not exist as a subject in its own right. At the postgraduate level, at least two UK universities have recently begun to offer master's programmes in rhetoric both of which appear to have a conventional emphasis on oratory. In contrast with the position in the UK and for no obvious reason, rhetoric has always had a strong and well-developed presence in US higher education and also in some continental countries.

So, whither the teaching of rhetoric and of marketing and the use of rhetorical devices by the technicians in marketing management? My contention, or conceit, would be that in the reality of the developed, wealthy, post-industrial world featuring consumer societies and competitive markets, much of modern day to day life as well as the social order more generally are defined by consumption, by ownership and by chosen experience such that while persuasion, or rhetoric, is pertinent to many disciplines and professions, it has a very obvious home either with or within marketing. Pushed further, some might propose that in the contemporary setting, marketing is the reincarnation of rhetoric. As Laufer and Paradeise suggested (op cit), 'The comparison between marketing and Sophism as persuasive techniques and as manifestations of the crisis of reason leads us to argue that marketing is the modern bureaucratic form of Sophism'. I agree wholeheartedly and perhaps the day will soon come when students on undergraduate or taught postgraduate programmes in marketing encounter an introductory text or a foundation module accurately titled 'Marketing: Rhetoric and Reality'. I was expecting something like this back in 1978.

\section{References}


Hunt, Shelby D. (1976). The Nature and Scope of Marketing. Journal of Marketing, 40 (July), 728.

Hackley, C. (2003). Marketing and Social Construction: Exploring the rhetorics of managed consumption. London: Routledge.

Williams, J. D (2009). An Introduction to Classical Rhetoric: Essential Readings. Chichester: Wiley-Blackwell.

Laufer, R. and Paradeise, C. (1990). Marketing Democracy: Public Opinion and Media Formation in Democratic Societies. London: Transaction Publishers.

Tonks D. G. (2002). Marketing as Cooking: Return of the Sophists. Journal of Marketing Management, 18(7/8), 803-822.

Kuhn, T. S. (1962). Structure of Scientific Revolutions. Chicago: University of Chicago Press.

\section{Conclusion by the Editors}

In concluding the invited contributions for this special section on marketing (as) rhetoric we would like to thank all of the authors for their enthusiasm and gladly-donated effort. It has been greatly encouraging to receive such positive contributions. Clearly, there is a wide variety of opinions and approaches on display here, but the central message that rhetoric is an important part of marketing comes through loudly and strongly. Indeed, the variety of perspectives serves to indicate the great potential for rhetoric to contribute across so many aspects of marketing theory and practice. We look 
forward to the increasing florescence of the rhetorical perspective in our discipline and hope that the contributions here aid in its guidance and encouragement.

\section{References}

Hunt, S. (2012). Explaining empirically successful marketing theories: the inductive realist model, approximate truth, and market orientation. AMS Review 2(1): 5-18.

Hunt, S. D. (2013). The inductive realist model of theory generation: Explaining the development of a theory of marketing ethics. AMS Review 3(2): 61-74.

Hunt, S. D. \& Morgan, R. M. (1995). The comparative advantage theory of competition. Journal of Marketing, 59 (April): 1-15.

Marsh, C. (2013). Classical Rhetoric and Modern Public Relations: An Isocratean Model. London: Routledge.

Tonks D. G. (2002). Marketing as Cooking: Return of the Sophists. Journal of Marketing Management, 18(7/8), 803-822. 